\title{
Sedimentary environment and palaeogeography of the ?Palaeocene-Middle Eocene Kashkan Formation, Zagros fold-thrust belt, SW Iran
}

\author{
Bizhan Yousefi Yeganeh", ${ }^{*}$, Sadat Feiznia², A.J. (Tom) van Loon ${ }^{3}$ \\ ${ }^{1}$ Department of Geology, Faculty of Science, Tarbiat Moalem University, Tehran, Islamic Republic of Iran; \\ e-mail: bizhan.yegane@gmail.com \\ ${ }^{2}$ Faculty of Natural Resources, Tehran University, Tehran, Islamic Republic of Iran; \\ e-mail: sfeiz@ut.ac.ir \\ ${ }^{3}$ Geological Institute, Adam Mickiewicz University, Maków Polnych 16, 61-606 Poznan, Poland; \\ e-mail: tvanloon@amu.edu.pl \\ "corresponding author
}

\begin{abstract}
The Kashkan Formation (?Palaeocene to Middle Eocene) in the Zagros fold-thrust belt, SW Iran, which is intercalated between to marine limestone formations, consists of conglomerates, sandstones and siltstones. The sedimentology and the palaeogeography of the Kashkan Formation had not received any attention thus far, but have now been studied in seven sections, situated in the province of Lorestan. The sediments form twelve lithofacies, three ichnosubfacies and seven architectural elements, which are described, depicted and analysed. The analysis leads to the conclusion that most sediments accumulated in a low-sinuosity, low-gradient braided-river system (characterised by mainly unidirectional palaeocurrent directions, and by sheetfloods), that occasionally showed meandering characteristics (represented by overbank deposits and large bars). The deposits of this system closely resemble those of the South Saskatchewan River in Canada, which is considered as the classical example of a sand-bed braided river. The river flowed roughly from North to South, as deduced by palaeocurrent indicators such as imbrication and large- to medium-scale trough cross-stratification (direction measured in the trough axes). This current direction is supported by the southward to south-westward thinning of the formation and by the diminishing average grain size in the same direction. The trace fossils in the Kashban Formation fit all in the Skoyenia ichnofacies, which has here three ichnosubfacies which allow a more detailed palaeoenvironmental reconstruction, indicating that the braided stream passed into the low-energy shoreface zone of a tidally-influenced sea.
\end{abstract}

Keywords: Kashkan Formation, Zagros fold-thrust belt, trace fossils, facies architecture, braided river, shoreface, Palaeocene, Eocene, Iran

\section{Introduction}

The Zagros fold-thrust belt (ZFTB), which extends for about $2000 \mathrm{~km}$ from south-eastern Turkey through northern Syria and Iraq to western and southern Iran (Fig. 1), is well known for its numerous giant hydrocarbon fields. It is also the most resources-rich fold-thrust belt of the world (Alavi, 2004). More than a hundred stratigraphic sections have been surveyed in various parts of the Zagros belt (see, among others, Leturmy \& Robin, 2010). One of the lithological units that were distinguished is the Kashkan Formation. Its name was proposed by 


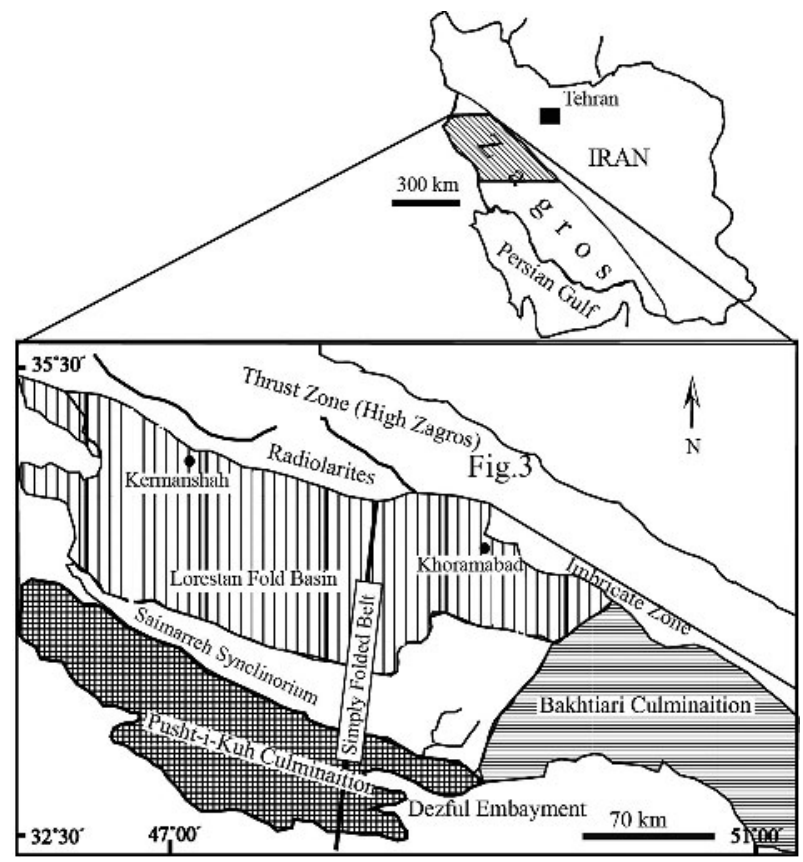

Fig. 1. Location and geological setting of the study area, showing structural parts of the Zagros fold-thrust belt in Iran (modified from Falcon, 1967).

James \& Wynd (1965), who assigned a ?Palaeocene to Middle Eocene age to this formation on the basis of its stratigraphic position; there are no index fossils (Motiei, 1993). The proposed name has been accepted and the formation has been adopted as a formal stratigraphic unit by the Stratigraphic Committee of Iran.
The Kashkan Formation rests upon the Palaeocene-Middle Eocene Talezang Formation and is overlain by the shallow-marine Middle-Late Eocene Shahbazan Formation (Fig. 2).

The entirely siliciclastic Kashkan Formation, of which the type section is located at kuh-e Amiran (the Amiran anticline) in the ZFTB, has received surprisingly little attention thus far. Neither a sedimentological analysis nor a palaeogeographical reconstruction has hitherto been performed. The present contribution describes and depicts the lithofacies, the architectural elements and the trace fossils of this formation, and reconstructs on this basis the sedimentary environment and the palaeogeography.

Most data for this study were obtained by measuring seven sections in the study area, which is located in the ZFTB in the province of Lorestan (SW Iran): they are named here the Darabi, Domsorkh, Mamoolan, Golgekhalag, Malavi, Moorani and Sepiddasht sections (Fig. 3).

\section{Geological setting}

\subsection{Pre-Tertiary history}

Following the late Precambrian Katangan orogeny, the craton on which Iran, Pakistan,

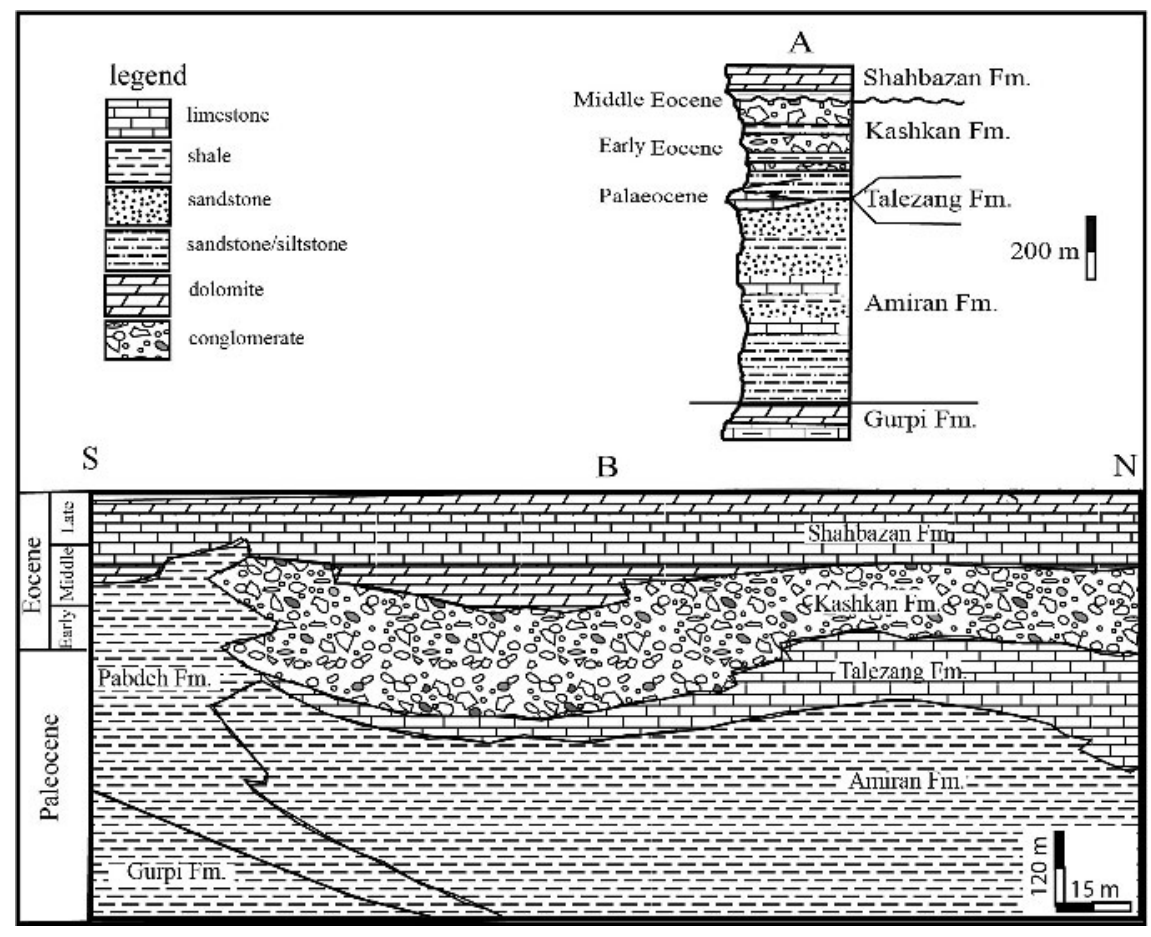

Fig. 2. The Kashkan Formation. A: Schematic sedimentary log of the type section. B: Schematic cross-section, showing the relationships with adjoining formations (modified after James \& Wynd, 1965). 


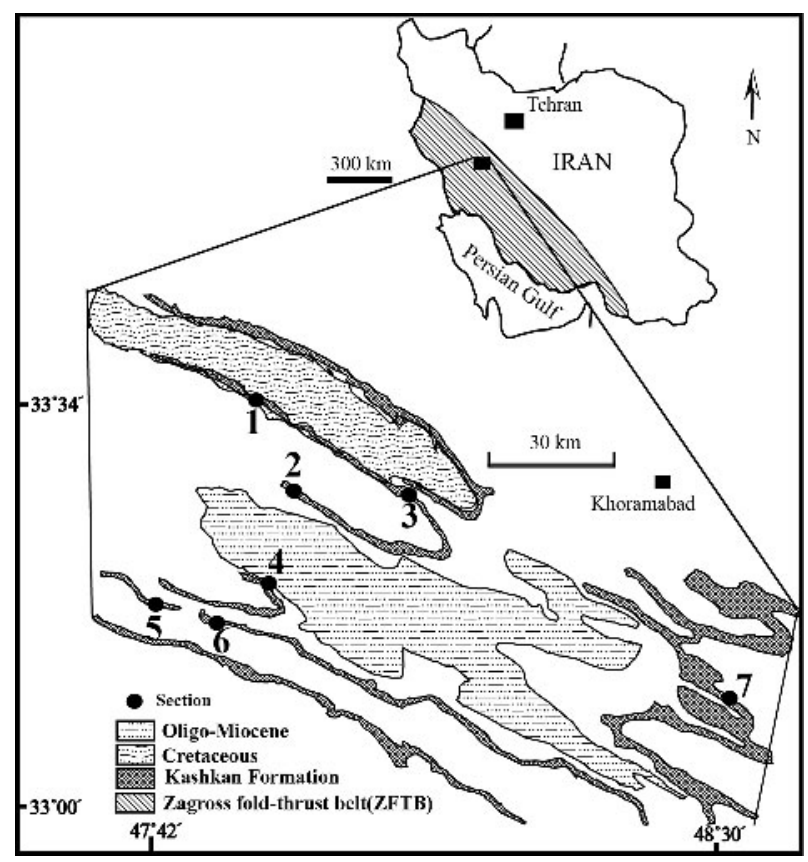

Fig. 3. Schematic geological map of the study area, with the locations of the sections under study. $1=$ Darabi, 2 = Domsorkh, 3 = Mamoolan, 4 = Golgekhalag, 5 = Moorani, 6 = Malavi, 7 = Sepiddasht section.

central Afghanistan, south-eastern Turkey and Arabia are situated, became a relatively stable continental platform where sediments accumulated on an epicontinental shelf. No major magmatism or folding then took place (Stocklin et al., 1964). Most of the Zagros Basin emerged during Late Ordovician to Early Silurian tectonics. The area underwent erosional activity until the end of the Late Palaeozoic, resulting in a sedimentary gap. During the Permian, a regional transgression followed, and the partly eroded Ordovician and Silurian became covered, via a low-angle unconformity, by Permian sediments of the Zagros Basin (Szabo, 1977).

During the Early Permian, an elongated zone of the Zagros Basin became uplifted and folded; this was defined by Szabo and Kheradpir (1978) as the Zagros fold-thrust belt. Unlike the Permian of Arabia, no glacigenic clastics have been found in the Zagros Basin. During Middle Triassic orogenic movements, all of Iran was folded and uplifted, except for the Zagros Basin where the movements were less intense (Berberian and King, 1981). Marine carbonates accumulated here throughout the Per- mian and Early Triassic (Szabo \& Kheradpir, 1978). Regressive conditions in the Middle Triassic resulted in the deposition of the evaporites, indicating hot and arid conditions (Stocklin, 1968). No Upper Triassic has been found in the Zagros so far (Szabo, 1977), probably as a result of a sea-level lowering.

The evaporites of the Zagros Basin became unconformably overlain by Liassic terrigenous clastics and transitional terrigenous-to-openmarine sediments. During the Late Jurassic, a carbonate platform extended from the Zagros Basin to northern central Arabia; the climate was probably more humid than before (Murris, 1978). The sea deepened during the Cretaceous, when a marine transgression occurred over most of Iran. The Cretaceous sediments follow the Jurassic succession disconformably. In the north-western part of the Zagros Basin (where now Lorestan is situated), Cretaceous grey-black radiolarians-bearing shales and deep-water argillaceous limestones were deposited disconformably over the Jurassic evaporites, and deeper-water sedimentation continued from the Albian to the Turonian. Late Turonian movements reactivated NWSE trends in Lorestan, where these trends had existed already since the Permian (James \& Wynd, 1965). In most parts of the Zagros Basin, the Upper Cretaceous starts with neritic carbonates, followed by deeper-water marls and shales. During the Campanian to Maastrichtian, the present-day Zagros trend became fully developed. At the end of the Maastrichtian an important regression took place, so that the overlying Palaeogene is separated from the Mesozoic by a major unconformity throughout the Zagros Basin (Setudehnia, 1978).

\subsection{Tertiary development}

The Zagros Basin was part of the southern margin of the Neo-Tethys Ocean (Murris, 1980) and became filled by terrigenous and carbonate sediments. The deepest part of this basin was located in the province of Lorestan, which covers the NW part of the basin. Geological interest in the Zagros Mountains in SW Iran was raised in the beginning of the $20^{\text {th }}$ century, 
when giant oil occurrences were discovered. Since the 1908 discovery, the main production has been from limestones of the Asmari Formation, an Oligo-Miocene limestone. This formation is overlain by the Talezang Formation, a reefal limestone. This unit is disconformably overlain by the Kashkan Formation, which is entirely siliciclastic in the study area, but which passes towards the SE into the limestones of the Shahbazan Formation.

The relatively coarse, siliciclastic character of the Kashkan Fm. makes this unit fairly exceptional in the total succession, and its lithofacies characteristics suggest that it is unlikely that hydrocarbons are present. That is most probably why thus far little attention has been paid to this formation. The present contribution is the first to provide a detailed sedimentological analysis and a reconstruction of the depositional environment.

\subsection{The Kashkan Formation}

The type section of the Kashkan Formation was established by James \& Wynd (1965) at kuh-e Amiran, where the Kashkan river cuts through the north-eastern flank of the anticline. The formation is composed here of deep-red coloured siltstones, sandstones and conglomerates, showing an overall coarsening-upward tendency from roughly $0.8-1.5 \mathrm{~cm}$ in the basal part to $2-3 \mathrm{~cm}$ in the top part. The bed thickness is $30-50 \mathrm{~cm}$, the size of the average clasts is $2-2.5 \mathrm{~cm}$ and the size of the largest clasts is $7-10 \mathrm{~cm}$.

The contact with the underlying Talezang Formation is abrupt (possibly a hiatus is present), whereas the upper boundary consists of a limonitic, weathered zone with dolomite layers of the Shabazan Formation. The siliciclastic Kashkan Formation is thus both underlain and overlain by limestones. All three formations have at least partly a Middle Eocene age in the type locality of the Talezang and Shahbazan Formations at the Tang-e Do. The Palaeocene-Middle Eocene age of the Talezang Fm. there has been proven by the occurrence of Miscellanea sp., Nummulites globules, Glomalveolina sp., Opertorbitolites curvispira and Halkyardia sp. The basal conglomerate of the Kashkan Formation directly overlies Palaeocene Talezang limestone in the Amiran anticline (the type section of the Kashkan Fm.) and has also been assigned there a ?Palaeocene age itself by James \& Wynd (1965); this implies that the lower boundary of the Kashkan Formation is strongly diachronous.

The accumulation of the Kashkan Formation resulted from the supply of clastic particles that had been eroded due to orogenesis in the area to the North-East (James \& Wynd, 1965). The formation becomes thinner and finer-grained in the southern part of the study

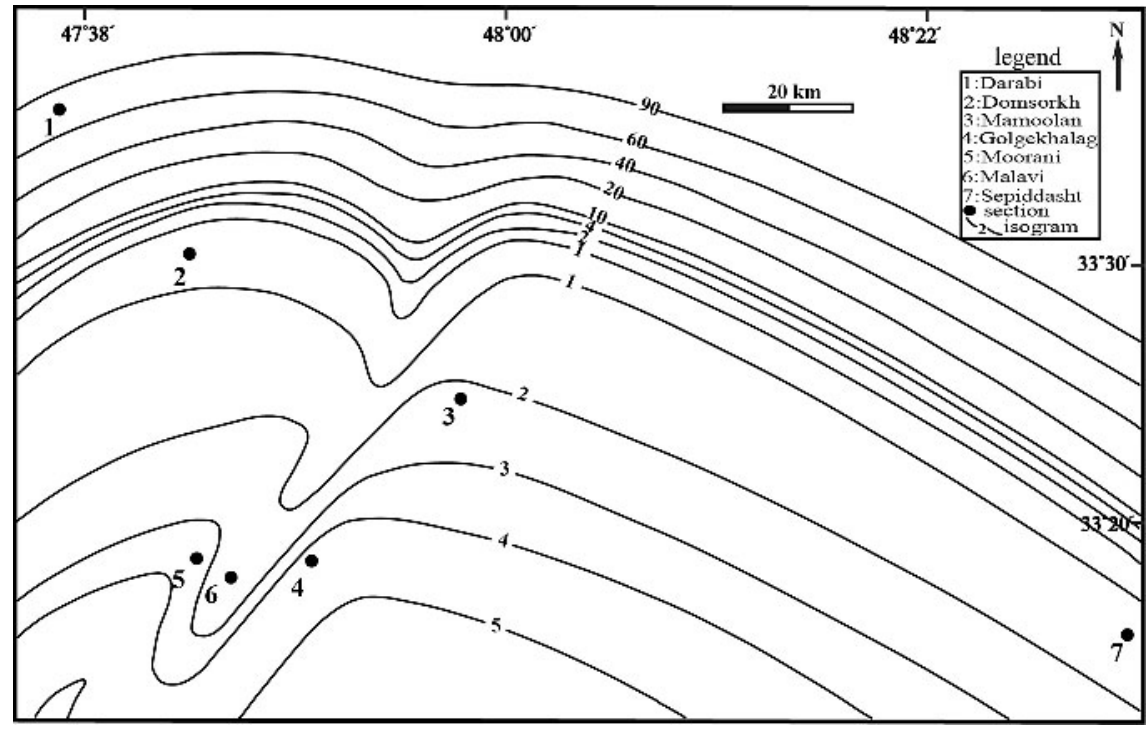

Fig. 4. Isoratio map (conglomerate + sandstone / shale) showing the diminishing dominance of coarse units towards the South. 
Fig. 5. Isoratio map (sandstone / shale) showing the increasing amount of fine-grained sediments towards the South.

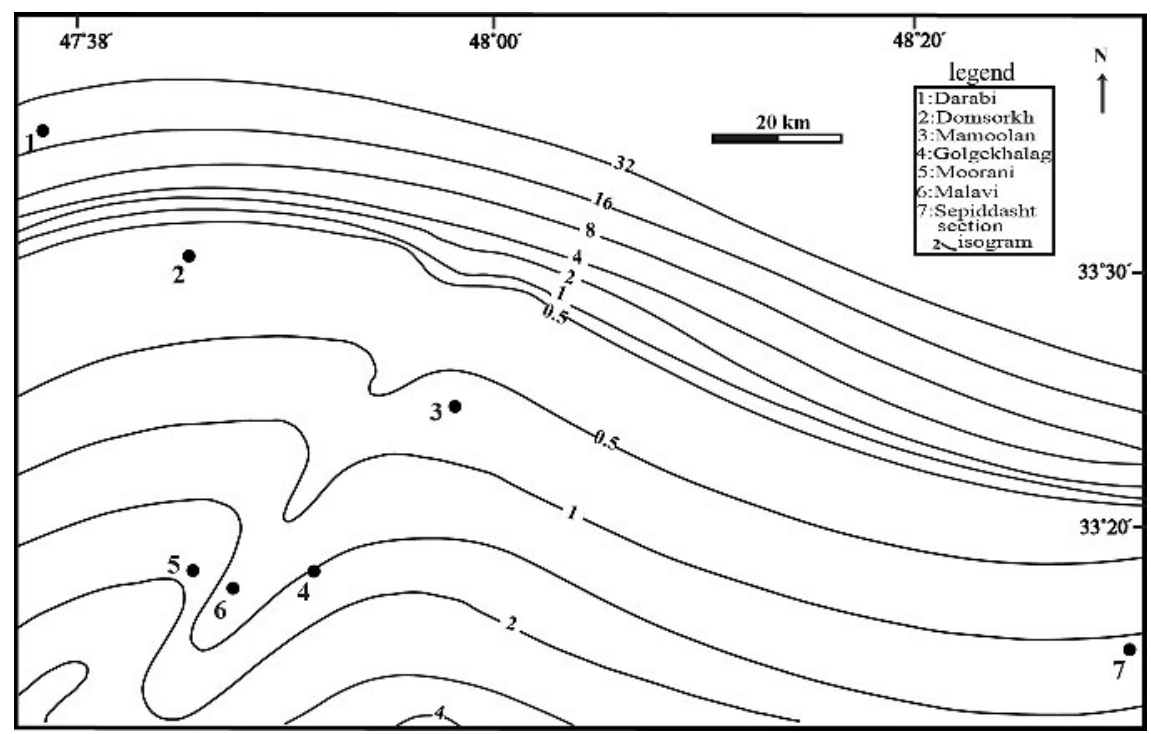

area (Figs 4-5). South-west from the type-section area, the Kashkan Formation interfingers, like the under- and overlying formations, with the Pabdeh Formation (Fig. 2).

\section{Methods}

The present study included analysis of the sedimentary facies and the architectural elements, and an inventory and facies interpretation of the trace fossils. As part of the collection of field data aimed at the reconstruction of the palaeogeography, palaeocurrent directions were determined from large- to medium-scale trough cross-stratification (direction measured in the trough axes) and from the imbrication of clasts. Clast analyses and palaeocurrent measurements were carried out exclusively in outcrops of at least $1 \mathrm{~m}^{2}$ in exposures perpendicular to the bedding, and only after cleaning the surface from lichens.

The analysis of the trace fossils did not restrict itself to identification and reconstruction of the habitat in which the animals lived, but included also the state of preservation and changes in the type and frequency of the trace fossils. Particularly the internal structure, size, wall nature, and branching of burrows were analysed.

\section{Lithofacies}

Twelve lithofacies have been distinguished. They are indicated in the following according to the lithofacies codes of Miall $(1985,1996)$. The seven sections that were studied in detail (Fig. 3) show various lithofacies that are presented here as sedimentary logs (Fig. 6).

\subsection{Massive conglomerates (lithofacies $\mathrm{Gm})$}

Facies Gm extends over tens of metres across various outcrops in the middle and upper parts of the Kashkan Formation. It generally consists of massive, clast-supported conglomerates with a matrix of coarse sandstone or gravel (2-4 $\mathrm{mm}$ ) filling the space between the larger clasts. The clasts are mostly rounded to sub-rounded, fine to coarse pebbles, but cobble-sized clasts also occur in the lower parts (Fig. 7-B,C). The lower boundary of this facies is erosional and irregular but the upper boundary is gradational, passing into much less coarse conglomerates. The conglomerates become thinner and finer in the southern part of the study area (Fig. 5).

The conglomerates form cycles in each of which the clast size decreases upwards (Fig. 

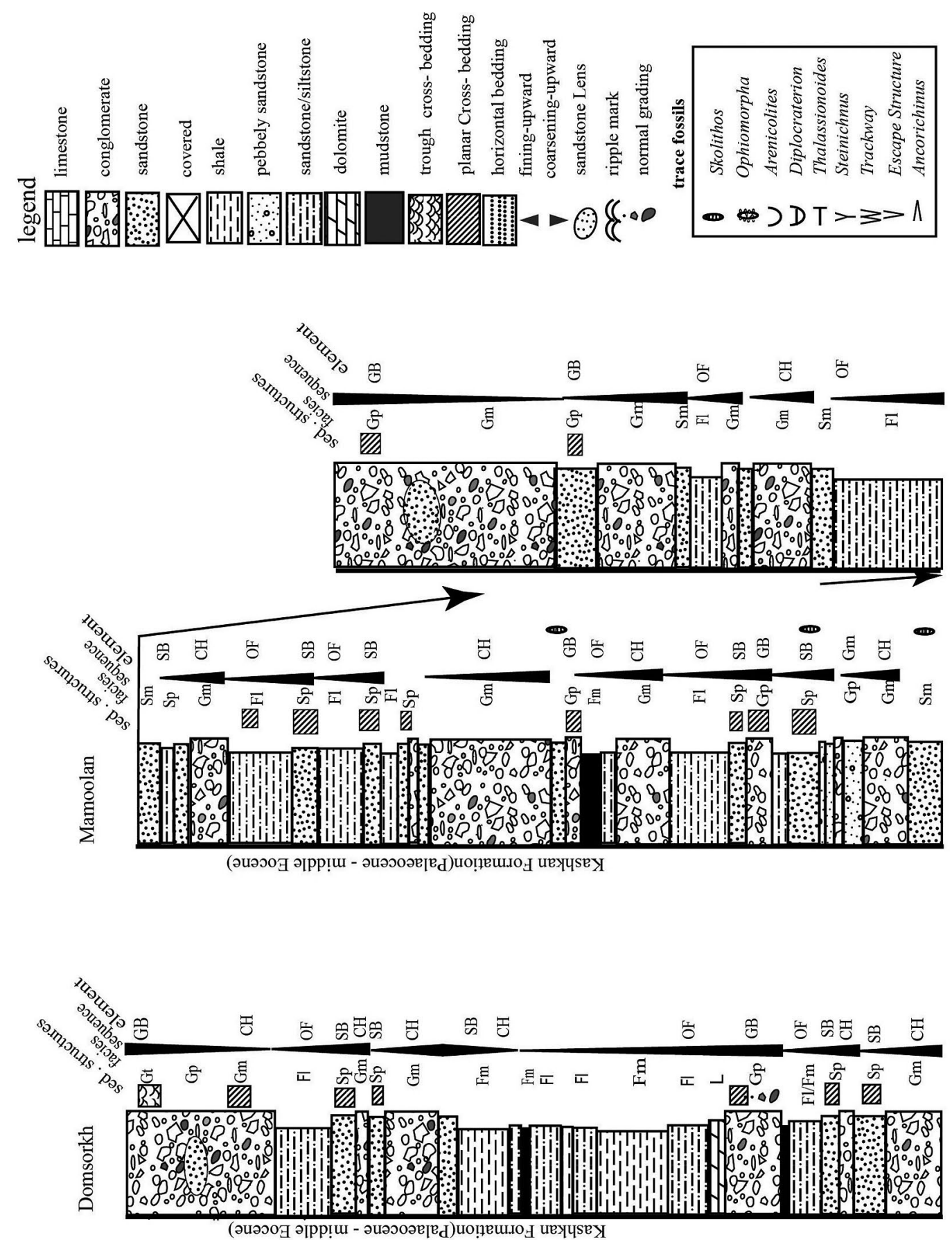

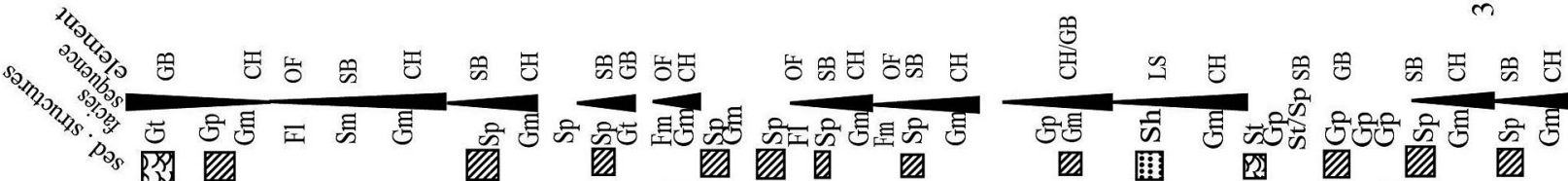

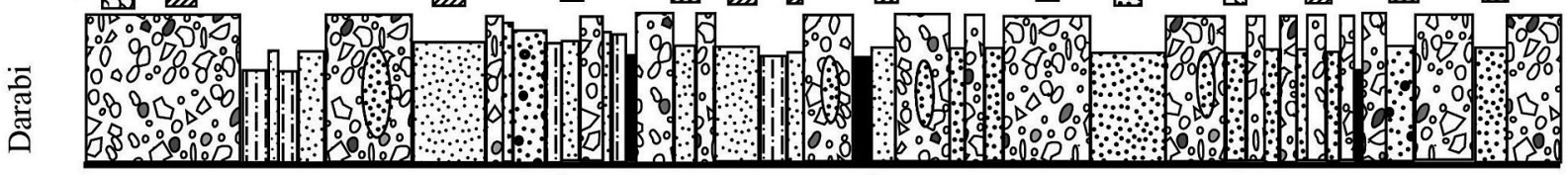



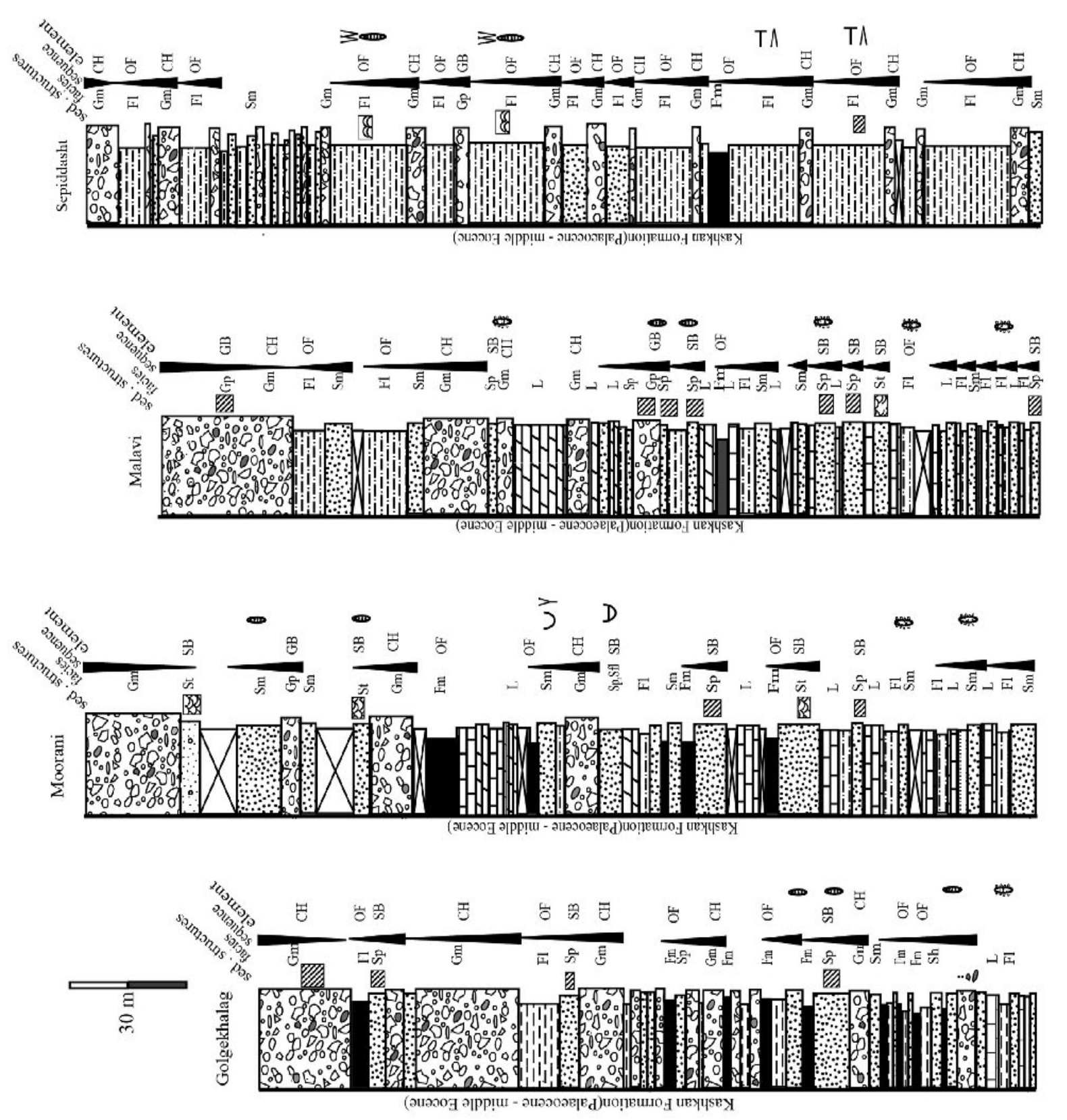

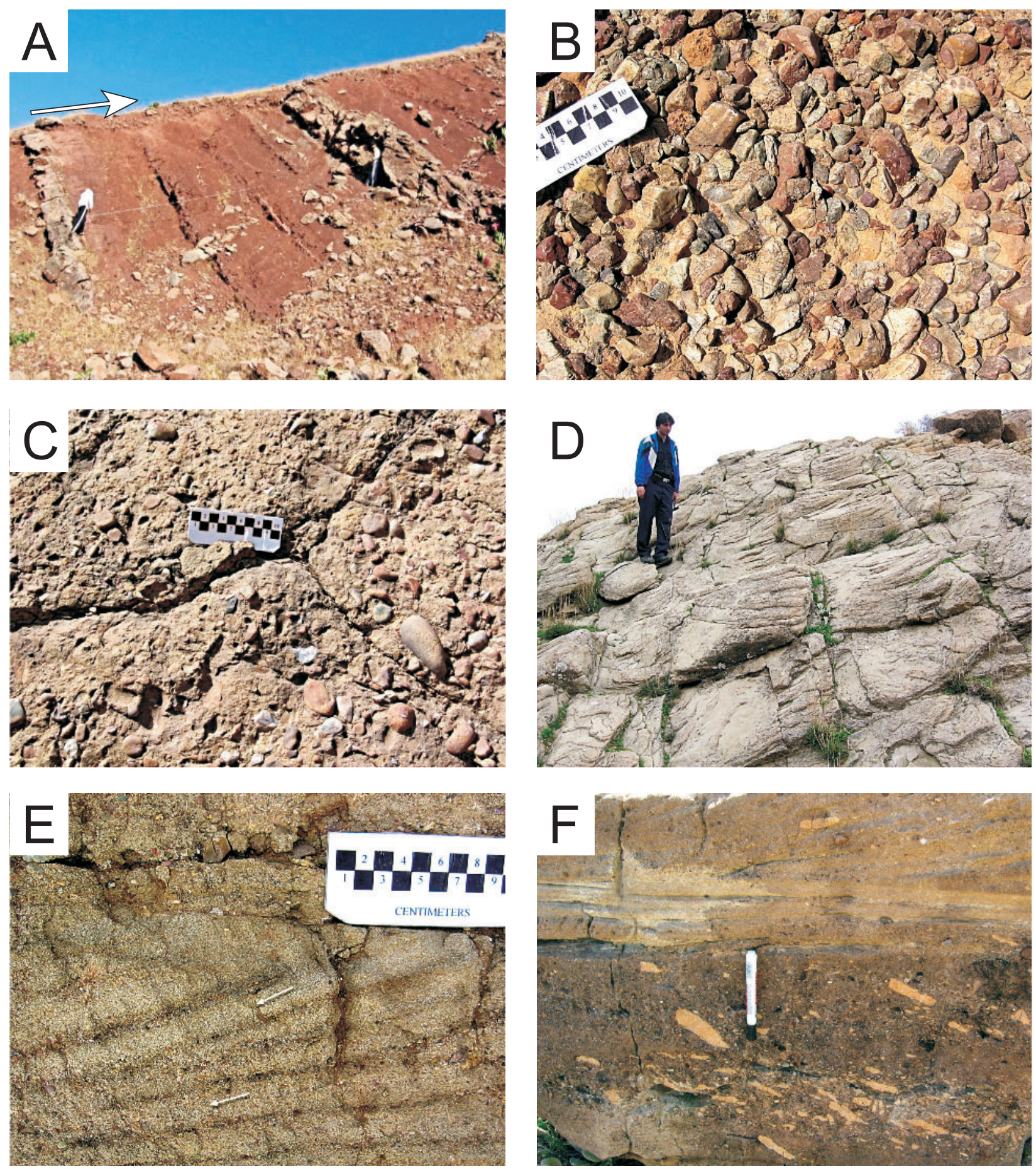

Fig. 7. Conglomerate facies Gm (A-C), Gt (D) and Gp (E, F). Scales are in cm. A: Fining-upward sequence from conglomerate to sandstone and siltstone. B: Massive lithofacies Gm. C: Lithofacies Gm with fine-grained matrix. D: Stacked trough cross-bedded conglomerates. E-F: Planar cross-bedded conglomerates.

7-A). Individual cycles are 0.5-6 m thick, and some cycles show amalgamation (Fig. 7-D).

Some lenses of cross-bedded, coarse-grained pebbly sandstone are present in this overall massive facies.

\subsection{Planar cross-stratified conglomerates (lithofacies Gp)}

Facies Gp consists mainly of clast-supported conglomerates with tabular cross-bedding, 
but some lenses of planar cross-bedded sandstones are also present. The facies is $0.5-1.5 \mathrm{~m}$ thick, with individual sets being mostly $25-50$ $\mathrm{cm}$ thick. The lower boundary of this facies is only locally erosional.

The mean dip of the foresets is $25^{\circ}$ (Fig. 7-E,F), commonly toward the south-west. Some of the foresets show erosional (re-activation) surfaces. The cross-bedded layers show normal grading.
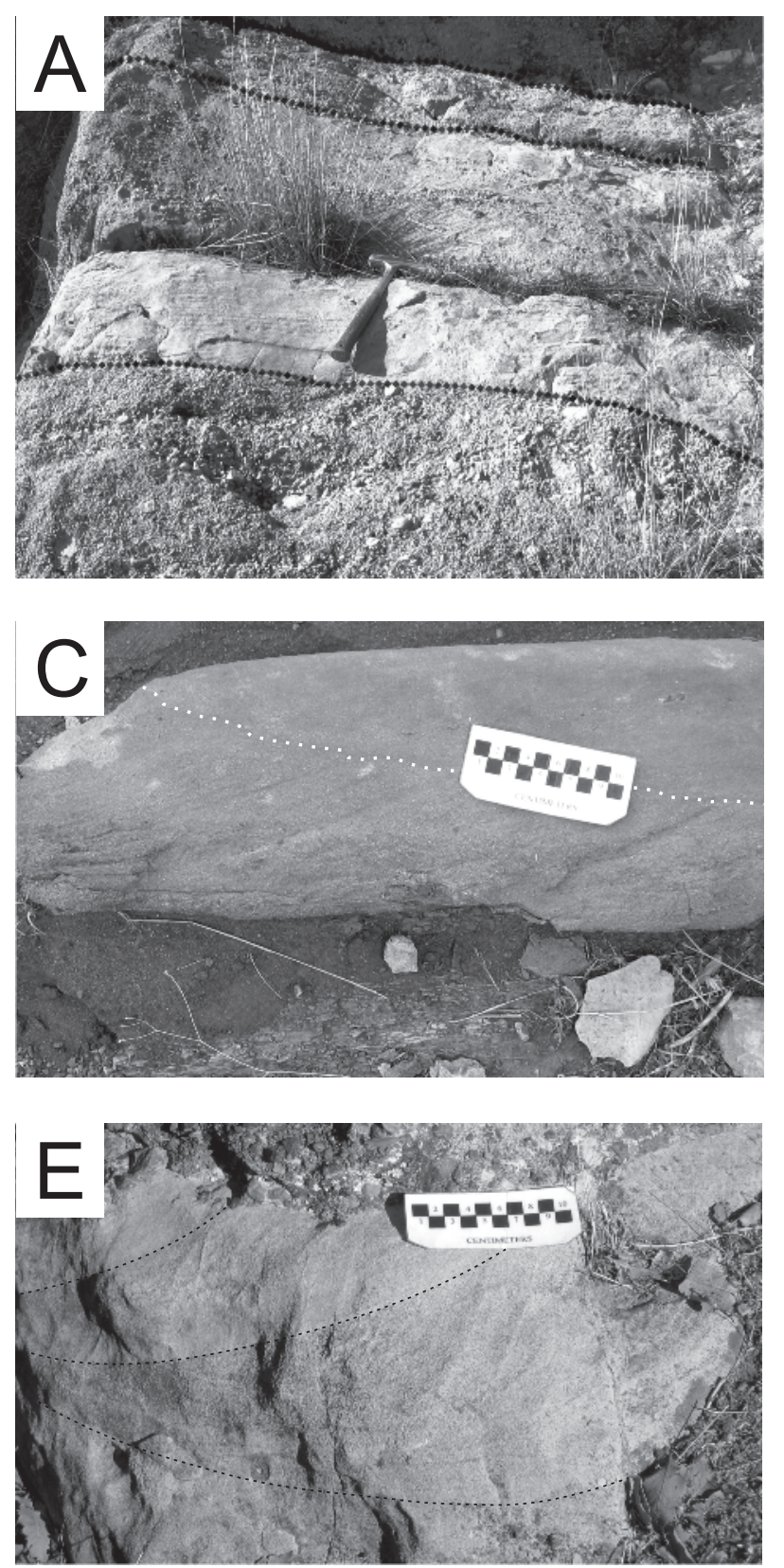

\subsection{Trough cross-stratified conglomerates (lithofacies Gt)}

Facies Gt is characterised by clast-supported, trough-shaped cross-bedded conglomerates, with a basis that shows both symmetrical and asymmetrical undulations (Fig. 8-A).

The clasts are generally similar to those of lithofacies $\mathrm{Gm}$, but they are somewhat smaller than in Gm. The cross-bedded sets are usually
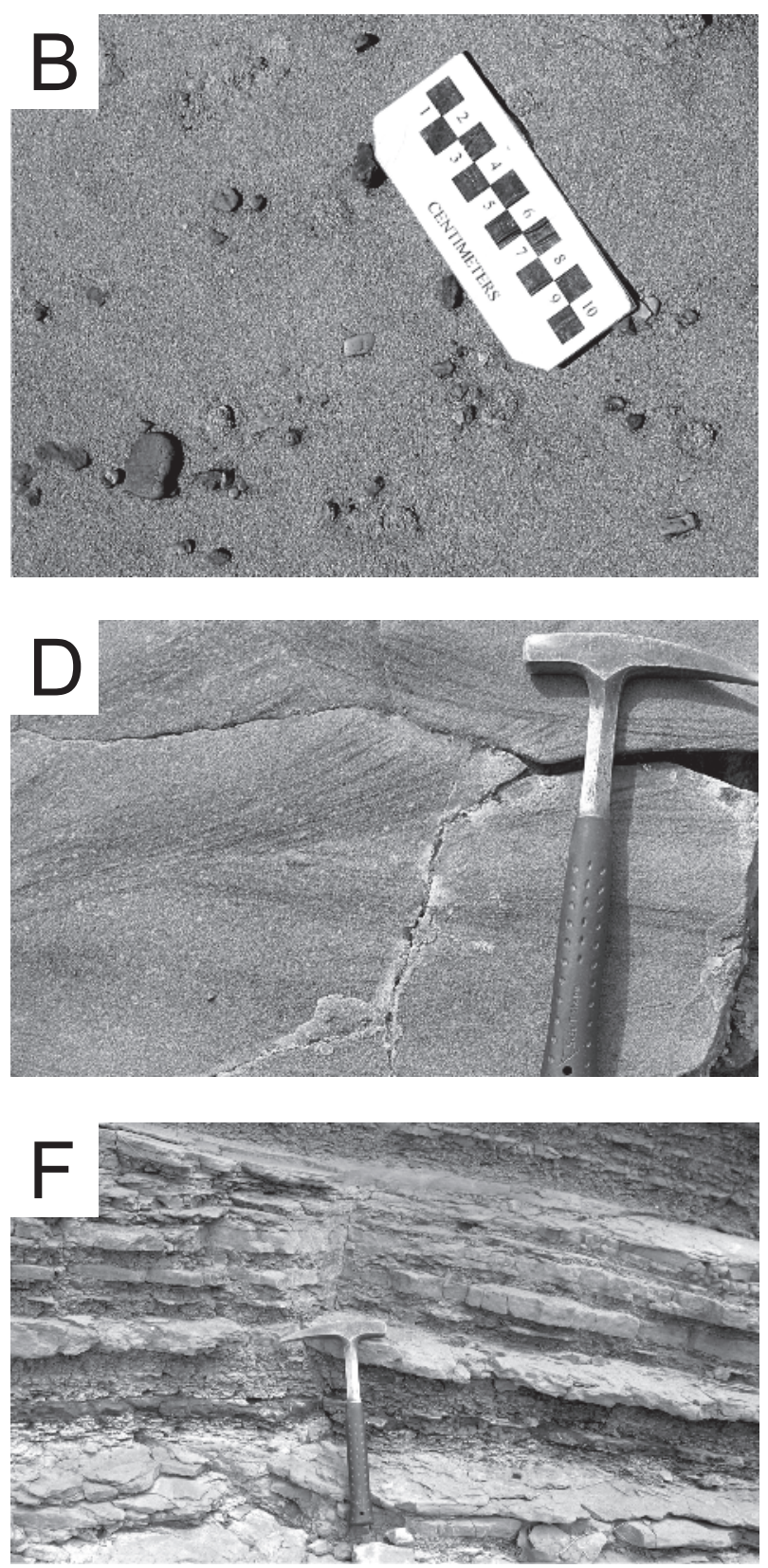

Fig. 8. Sandstone lithofacies Sm (B-C), Sp (C), St (D-E) and Sh (F). Scales in cm. A: Trough cross-stratified conglomerates (Gt). B: Massive sandstone (Sm). C: Erosional contact between Sp and Sm. D-E: Close-up of trough cross-stratified sandstone St. F: Horizontally stratified sandstone (Sh). 
graded. The palaeocurrent direction, as measured from the trough axes, is most commonly towards the south-west.

Lenses of planar to trough cross-bedded sandstones ( $\mathrm{Sp}$ and $\mathrm{St}$ ) are also present. The individual sandy units are $0.5-1 \mathrm{~m}$ thick and usually 1-3 $\mathrm{m}$ wide.

\subsection{Massive pebbly sandstones (lithofacies Sm)}

Facies Sm comprises massive beds of medium- to coarse-grained sandstones. The lower boundary is locally erosional, though not always distinctly, but the upper boundary is commonly sharp, often undulating or irregular. The thickness of individual beds varies between 0.2 and $1.5 \mathrm{~m}$. The grains are poorly to well sorted, and well-rounded to subrounded. Rare floating pebbles or gravels are present (Fig. 8-B).

\subsection{Planar cross-bedded sandstones (lithofacies Sp)}

Facies Sp consists of medium- to very coarsegrained sandstones. Scattered quartz and chert pebbles of various colours are present in some beds, thus forming pebbly sandstones (Fig. $8-\mathrm{C})$. Some lenses with more frequent pebbles occur, thus forming lenses of conglomeratic sandstone. Facies Sp is lenticular or irregularly wedge-shaped. The lower boundary of this facies is sharp, whereas the upper boundary is erosional.

Planar cross-stratification is present in solitary sets or as cosets. Cross-sets are $15 \mathrm{~cm}$ to a few decimetres thick. Most foresets are fining upward and dip toward the south-west. The thickness of these planar cross-bedded sets typically decreases with decreasing grain size.

\subsection{Trough cross-bedded sandstones (lithofacies St)}

Facies St consists of medium- to very coarse-grained, moderately to poorly sorted sandstones. Some of the sandstones contain scattered cherty pebbles. This facies forms lenticular or wedge-shaped bodies.

The sandstones are well stratified, with sets and cosets, with sharp boundaries between them, commonly marked by thin siltstone layers. Sandstone layers with trough crossbedding dominate. They are $10-80 \mathrm{~cm}$ thick (Fig. 8-D,E); the thickness is, as a rule, proportional to the grain size. The cross-bedding is of a low-angle type, and the troughs show a long wavelength (of some tens of centimetres on average). The trough axes dip commonly toward the south-west.

\subsection{Horizontally stratified sandstones (lithofacies Sh)}

Facies Sh consists of moderately to well sorted, horizontally stratified fine to coarse sandstone layers, which alternate. This facies is present within all other sandstone facies. Parting lineation is visible at the surface of very fine to fine sandstones (Fig. 8-F).

Each unit is about a few decimetres to a few metres thick. The upper and lower boundaries with other facies are sharp. The bounding surfaces may be traced for tens of metres.

\subsection{Ripple cross-laminated sandstones (lithofacies Slr)}

Facies Slr consists of moderately to well sorted, fine to coarse sandstones with thin intercalations of laminated siltstones. This facies is yellow to chocolate-coloured (Fig. 9-A). The grain size decreases upwards, simultaneously with thickening of the intercalated siltstones. The layers show an irregularly undulating lamination, with thin mud laminae on top of the sandy beds; some either asymmetrical or symmetrical ripples are present. 


\subsection{Flaser laminated sandstones (lithofacies Sfl)}

Facies Sfl consists mainly of moderately sorted, wavy layers of fine sandstones and siltstones. The finest sediments occur as thin laminae, which are confined to ripple troughs (Fig. 9-B). This type of bedding is known as wavy flasers; the sediments represent ripple troughs and crests without a continuous bed form.

\subsection{Massive mudstones (lithofacies Fm)}

This facies mainly consists of siltstones and homogeneous mudstones, with a minor portion of fine- to coarse-grained sandstones that are scattered within this facies in the form of thin layers of nodular patches. The facies has a sheet-like geometry and its colour varies from brownish red to dark red to purple.

The lower boundary is commonly flat and irregular. Although facies Fm is generally massive, it contains rain-drop imprints and desiccation cracks indicating subaerial exposure during sedimentation (Mazumder \& Sarker, 2004; Bridge, 2006).

\subsection{Laminated mudstones (lithofacies F1)}

This sheet-like facies is composed mainly of parallel laminated siltstones (or mudstones) and shales. The lamination is caused by alternations of mudstone and siltstone. The lower

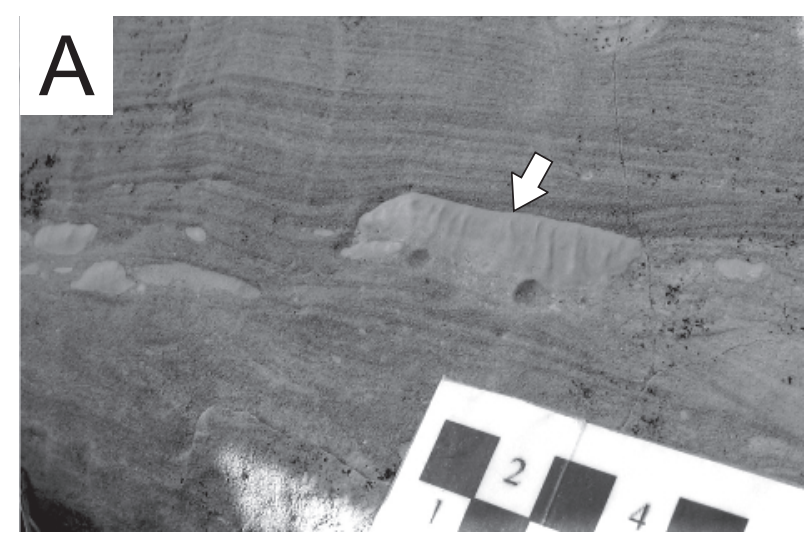

boundaries of the laminae are often erosional. The lower and upper boundaries of the individual beds are generally sharp and planar. Each unit is $10-80 \mathrm{~cm}$ thick.

\subsection{Carbonate mudstones/wackestones (lithofacies L)}

This facies is characterised by milky white to gray massive mudstone/wackestones with bioclastic fragments such as foraminifers (Figs 10-A, B, C). The upper and lower boundaries are sharp and planar, and are a few decimetres to a few metres thick. In some cases, fossils were selectively dolomitised.

\section{Architectural analysis}

As will be discussed below, the combination of the various lithofacies is a first indication of an overall fluvial setting. It was therefore decided to analyse also the architectural elements of the Kashan Formation, as the application of concepts on fluvial architecture and sandstone body-forms (Allen, 1983; Friend, 1983; Hirst,1991; Miall, 1985, 1994 ,1996; Jones et al., 2001) gives more insight into fluvial sequences (López-Gómez et al., 2009). The architecture is particularly important because a river can produce a wide variety of facies sequences, and because similar sequences can be formed in rivers of different styles (Bridge, 1985; Miall, 1996; Salamon \& Zielinski, 2010). Architectural analysis pays particular attention to large-

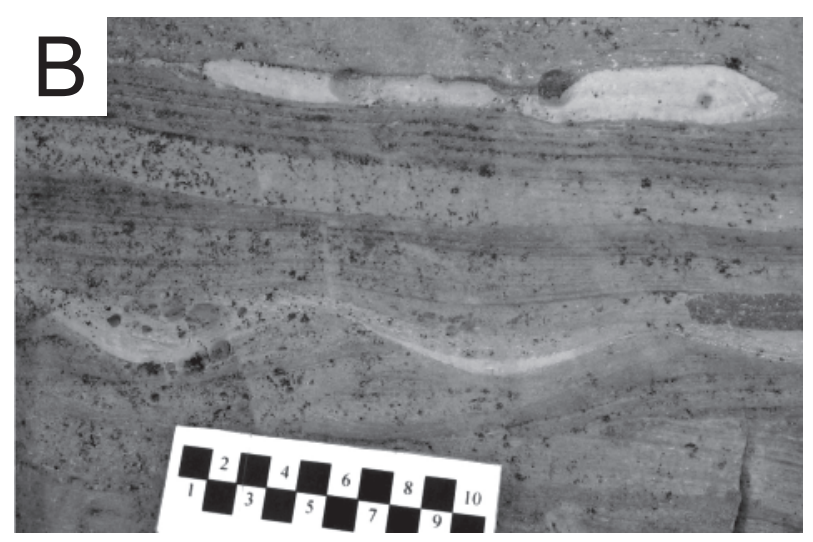

Fig. 9. Structures in sandy lithofacies. Scales in cm. A: Ripple cross-laminated sandstone (lithofacies Slr). Arrow shows a mudstone clast. B: Flaser-laminated sandstone (lithofacies Sfl). 

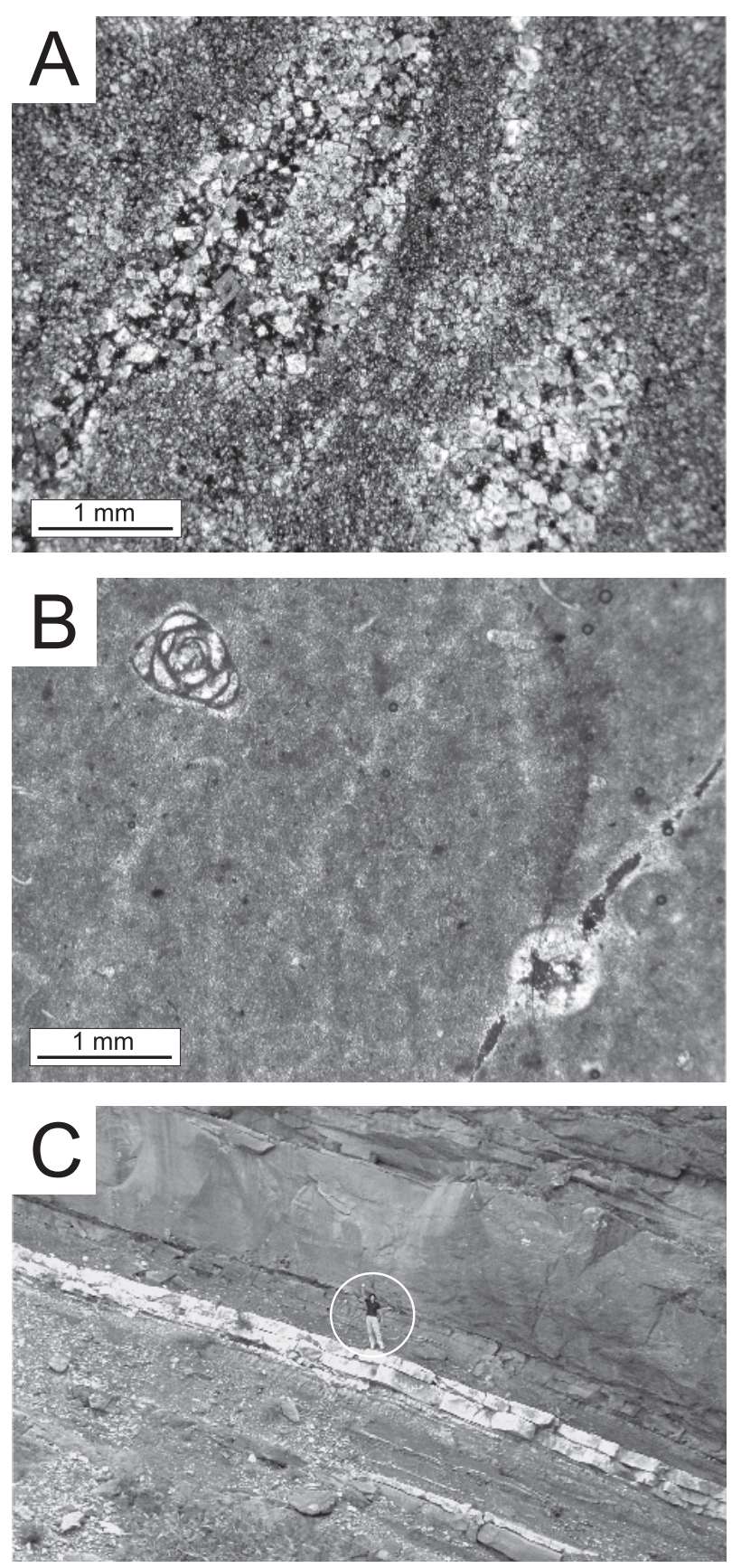

Fig. 10. Shoreface lithofacies L. A: Dolomitized fossil fragments. B: Micrite with miliolid foraminifer. C: Milky white limestone, man for scale.

scale sedimentary structures that are believed to reflect the type and behaviour of bars and channels (Allen,1983, 1985, 1988, 1994; Willis, 1993). The reorganisation of large morphological expressions of rivers such as bars and channels by architectural analysis is crucial for the interpretation of ancient fluvial systems (Allen, 1983; Miall, 1988). Architectural elements can be defined on the basis of large-scale stratal patterns and constituent facies (Miall,1988). The spatial arrangement of the various elements reflects the spatial relationships between the morphological units and the changing positions of channels within a channel belt (Miall, 1994; Brierley, 1996).

The architectural elements in the Kashkan Formation have been identified on the basis of Miall's (1985) classification. The individual architectural elements have a hierarchical arrangement, with some smaller elements occurring within larger elements.

\subsection{Channel-fill element (CH)}

The channel-fill element is characterised in the Kashkan Formation by stacked, multi-storey channel bodies that incise the underlying sediments. The boundaries are, as a rule, undulatory, showing low-angle accretion surfaces. A channel fill often comprises the facies $\mathrm{Gm}$, Gt and Gp, with subordinate facies St/Sp that are covered by facies Fm and Fl. The individual channel-fill elements have all a lenticular geometry, and can be traced laterally up to 300 m (Fig. 11-A).

This element abounds in the middle and upper parts of the Kashkan Formation.

\subsection{Gravel-bar element (GB)}

The gravel-bar element consists of vertically stacked layers of facies Gp and Gt and forms wedges or shows a lenticular form. Most of these elements show a fining-upward trend. They occur as isolated forms but are also found within element $\mathrm{CH}$ (Fig. 11-B).

\subsection{Sandy-bedform element (SB)}

The sandy-bedform element is composed of trough-shaped or planar sandstone bodies. It forms wedges or has a lenticular shape, and it is overlain by thin, sheet-like medium- to finegrained sandstone beds or even finer-grained sediments. Facies Sp and St are the constituents; they become thinner towards the top of the SB 

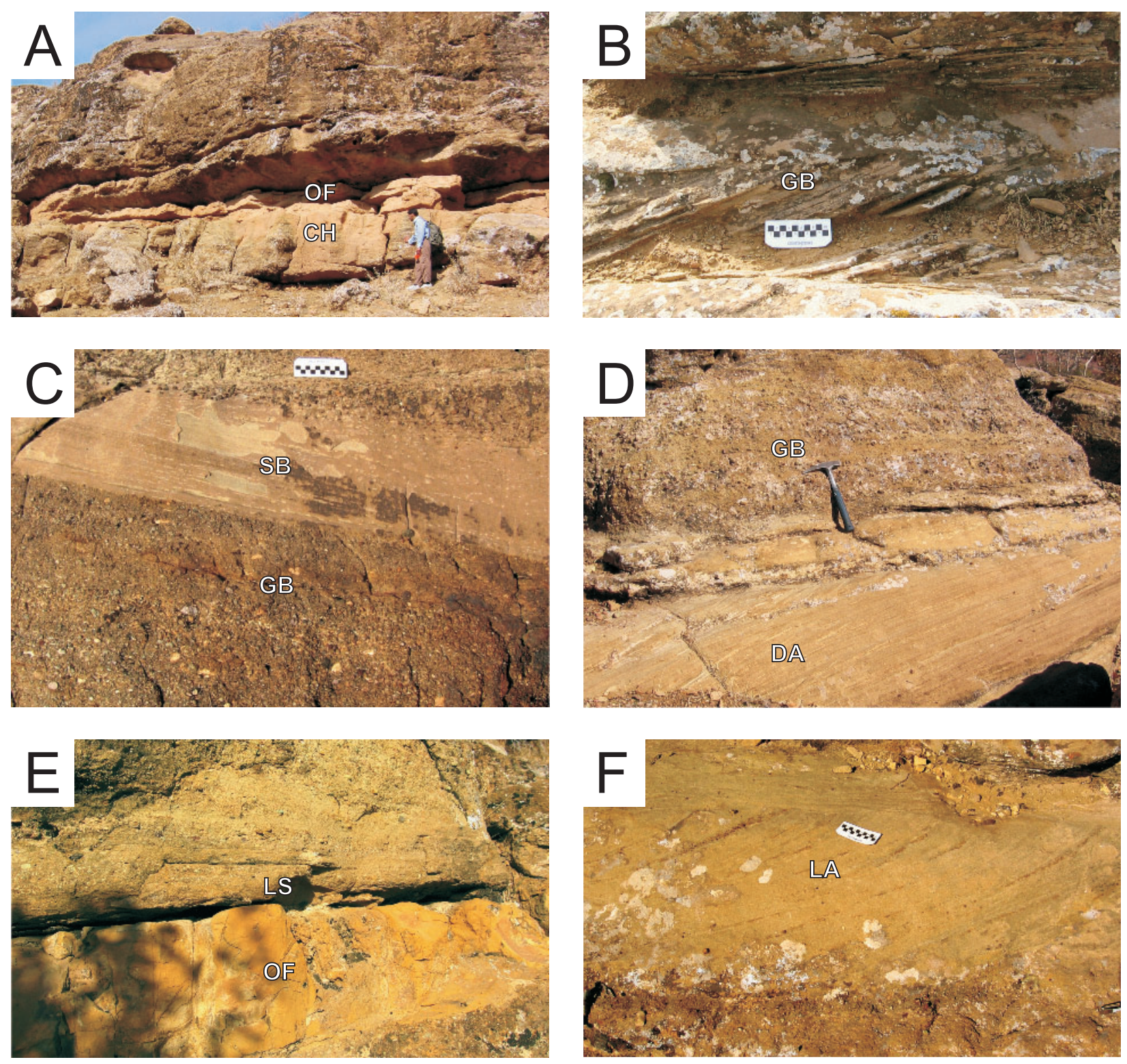

Fig. 11. Architectural elements. A: Channel fill element $(\mathrm{CH})$ and floodplain element (OF). B: Gravel-bar element (GB). C: Gravel-bar element (GB) and sandy-bedform element (SB). D: Downstream-accretion element (DA). E: Laminated-sand-sheet element (LS). F: Lateral-accretion element (LA).

element (Fig. 11-C). The trace fossils Diplocraterion and Skolithos occur in this element.

\subsection{Downstream-accretion element (DA)}

The downstream-accretion element consists of low-angle accretion units with internal grading; it is composed of medium- to coarsegrained sandstones of facies Sp. This element, which is lenticular in shape (Fig. 11-D), forms a fining-upward granulometry in its lower part. It tends to show a convex-up shape for the entire element, but commonly also for individual units within a single element (cf. Miall, 1985). The trace fossil Skolithos occurs in this element.

\subsection{Laminated-sand-sheet element (LS)}

The laminated-sand-sheet element occurs in the upper part of fining-upward cycles, where it is usually associated with element $\mathrm{Fl}$ (Fig. 11-E). This element is up to $0.5 \mathrm{~m}$ thick, and mostly has a sheet-like shape. LS consists 
of fine-grained sandstones that are laterally continuous for about $15 \mathrm{~m}$. Laminites kaitiensis, Diplocraterion, Ophiomorpha, Thalassinoides and escape structures are trace fossils in this element.

\subsection{Floodplain element (OF)}

The sheet-like floodplain element occurs in the upper parts of all cycles in the Kashkan Formation. It is characterised by red shales with intercalations of fine-grained sandstone beds. The element has a lateral extension of about $100 \mathrm{~m}$ and its thickness from $20 \mathrm{~cm}$ to $105 \mathrm{~cm}$ (Fig. 11-E). Trace fossils are present in the form of trackways.

\subsection{Lateral-accretion element (LA)}

The lateral-accretion element is characterised by units of 1-2 $\mathrm{m}$ thick and $20 \mathrm{~m}$ wide (Fig. 11-F). It is dominated by fining-upward packages composed of fine- to medium-grained sandstones forming low-angle, planar composite cosets. Skolithos is the only trace fossil found in this element.

\section{Trace fossils}

Structures formed by the action of plants and animals are classified as bioturbations (Van Loon, 2009); the group consisting of trac- es left by any movement (or resting) of animals is known as trace fossils or ichnofossils. Some animals graze or crawl on the sedimentary surface, other species rest or live just below it, whereas still other animals construct much deeper burrows for dwelling or feeding. It is rarely known which trace fossils in the geological record have been produced by a specific species, but is has been found that different trace fossils were produced by animals living at different depths and in different environments.

Consequently, trace fossils can be useful for palaeoenvironmental studies, especially as tools for distinguishing between marine and non-marine deposits in the rock record. In general, trace fossils tend to be more abundant, diverse and morphologically distinctive in a marine than in a non-marine setting (D'Alessandro et al., 1987). In addition, in the numerous environmental settings where body fossils are poorly preserved, trace fossils may provide the only evidence of past life; they are an integral part of the substrate and cannot readily be transported (Crimes \& Droser, 1992).

Ichnological analysis thus can yield information on the depositional environment and water depth, rates and styles of deposition, sequence-stratigraphic markers of environmental change, any limiting stress factors such as oxygen abundance and salinity levels (Stow, 2005). The trace fossils from the Kashkan Formation, represented mainly by endichnial traces, have therefore been inventoried, and they

Table 1. Occurrence of ichnofossils in the various lithofacies.

\begin{tabular}{|c|c|c|c|c|c|c|c|c|c|c|c|c|}
\hline \multirow{2}{*}{ Ichnofossil type } & \multicolumn{12}{|c|}{ Lithofacies type } \\
\hline & Gm & Gp & Gt & Sm & Sp & St & Sh & Slr & Sfl & Fm & $\mathrm{Fl}$ & $\mathrm{L}$ \\
\hline Arenicolites & & & & $\mathrm{A}$ & & & $\mathrm{C}$ & & & & & \\
\hline Diplocraterion & & & & & $\mathrm{R}$ & & $\mathrm{C}$ & & & & & \\
\hline Laminites kaitiensis & & & & $\mathrm{C}$ & & & $\mathrm{R}$ & & & & & \\
\hline Ophiomorpha & & & & $\mathrm{C}$ & & & $\mathrm{R}$ & & & & & \\
\hline Skolithos & & & & A & $\mathrm{C}$ & & & $\mathrm{R}$ & & & & \\
\hline Steinichnus & & & & $\mathrm{R}$ & & & & & & & & \\
\hline Thalassinoides & & & & & & & $\mathrm{C}$ & & & & & \\
\hline escape structure & & & & & & $\mathrm{R}$ & & & & & & \\
\hline trackway & & & & $\mathrm{R}$ & & & & & $\mathrm{C}$ & $\mathrm{C}$ & & \\
\hline
\end{tabular}

$\mathrm{A}=$ abundant; $\mathrm{C}=$ common; $\mathrm{R}=$ rare. 
are described below shortly. Table 1 shows the distribution of the trace fossils found in the reconstructed palaeoenvironmental setting of the Kashkan Formation. It in worth mentioning here that only the massive pebbly and horizontally-bedded sandstones and the laminated or massive mudstones contain trace fossils. The other lithofacies are barren.

\subsection{Description of the trace fossils}

The trace fossils in the Kashkan Formation consist of typical burrows (in alphabetical order Arenicolites isp., Diplocraterion isp., Laminites kaitensis, Ophiomorpha isp., Skolithos isp, and Steinichnus isp.), escape structures and trackways.

Arenicolites isp. (Fig. 12-B) consists of simple, vertical U-shaped tubes without spreiten. It is commonly preserved in full relief. In plane view, it may be recognised by paired openings. Arenicolites is abundantly present in the Sm and Sh lithofacies.

Diplocraterion isp. occurs in the Kashkan Formation as vertical U-shaped 'Spreiten' burrows (Fig. 12-D). The limbs of the U are often divergent. The space between the 'Spreiten' is filled by yellow mud. The size of these traces ranges from 5 to $15 \mathrm{~cm}$. This trace fossil is abundant in the Sp and Sh lithofacies.

Laminites kaitiensis occurs mainly as simple to horizontal burrows filled with chevronshaped menisci backfill (Frey and Pemberton, 1984) (Fig. 12-A). It is abundant in the Sm and Sh lithofacies.

Ophiomorpha isp. ranges from simple individual burrows to complex networks consisting of cylindrical tunnels and shafts that typically bifurcate at acute angles (cf. Frey et al., 1978). The burrows are lined with agglutinated pelletoidal sediment (Pemberton et al., 2001). Ophiomorpha is sensitive to stability of the substratum, grain size, energy levels and rate and nature of sedimentation (Anderson \& Droser, 1998). The Ophiomorpha traces from the Kashkan Formation are found in some wellsorted sandstones. The interior of the burrows is commonly smooth, but rarely can be irregular due to pelleting. The burrows are support- ed by a yellow mud lining wall (Fig. 12-E,F). This trace fossil is abundant in the Sm and Sh lithofacies.

Skolithos isp. is a vertical to subvertical, straight to curved, unbranched burrow. The burrows are relatively short, up to about 20 $\mathrm{cm}$. They are unlined, with commonly smooth walls; occasionally, changes in diameter occur. The burrow fills are composed of fine-grained sediments that are less cemented than the host sediment and that have a different colour. This trace fossil is common in fine- to mediumgrained, poorly sorted sandstones of the Sm, Sp and Slr lithofacies (Fig. 13-A,B).

Steinichnus isp. is a cylindrical burrow that may or may not show T- and Y-branching (Fig. 13-C). This trace fossil is abundant in lithofacies $\mathrm{Sm}$.

Thalassinoides isp. is present in the Kashkan Formation as large branched burrows with a smooth surface. These burrows are Y- to Tshaped and become wider at the points of bifurcation (Fig. 13-D). The sizes of the burrows are fairly identical and their cross-sections vary from half-moon-shaped to cylindrical. This trace fossil is abundant in the Sh lithofacies.

Escape structures are formed by organisms when they try to escape from a sudden burial under sediment after a short pulse of sedimentation. The escape burrows show chevron-like laminations, indicating the upward movement of the organism (Fig. 13-E). Escape structures are abundant in lithofacies Sh.

Trackways can be left by several types of walking vertebrates. Birds and mammals are the most common producers. Tracks represent walking, running, sliding and resting. This trace fossil is abundant in lithofacies Fm and Fl.

\subsection{Ichnofacies}

As trace fossils do not occur randomly but rather occur in specific combinations that are related to the sedimentary environment, they can be grouped in ichnofacies. Initially, ichnofacies were supposed to depend on a basin's depth (Seilacher, 1957), but it is now recognised that they rather are a manifestation of be- 

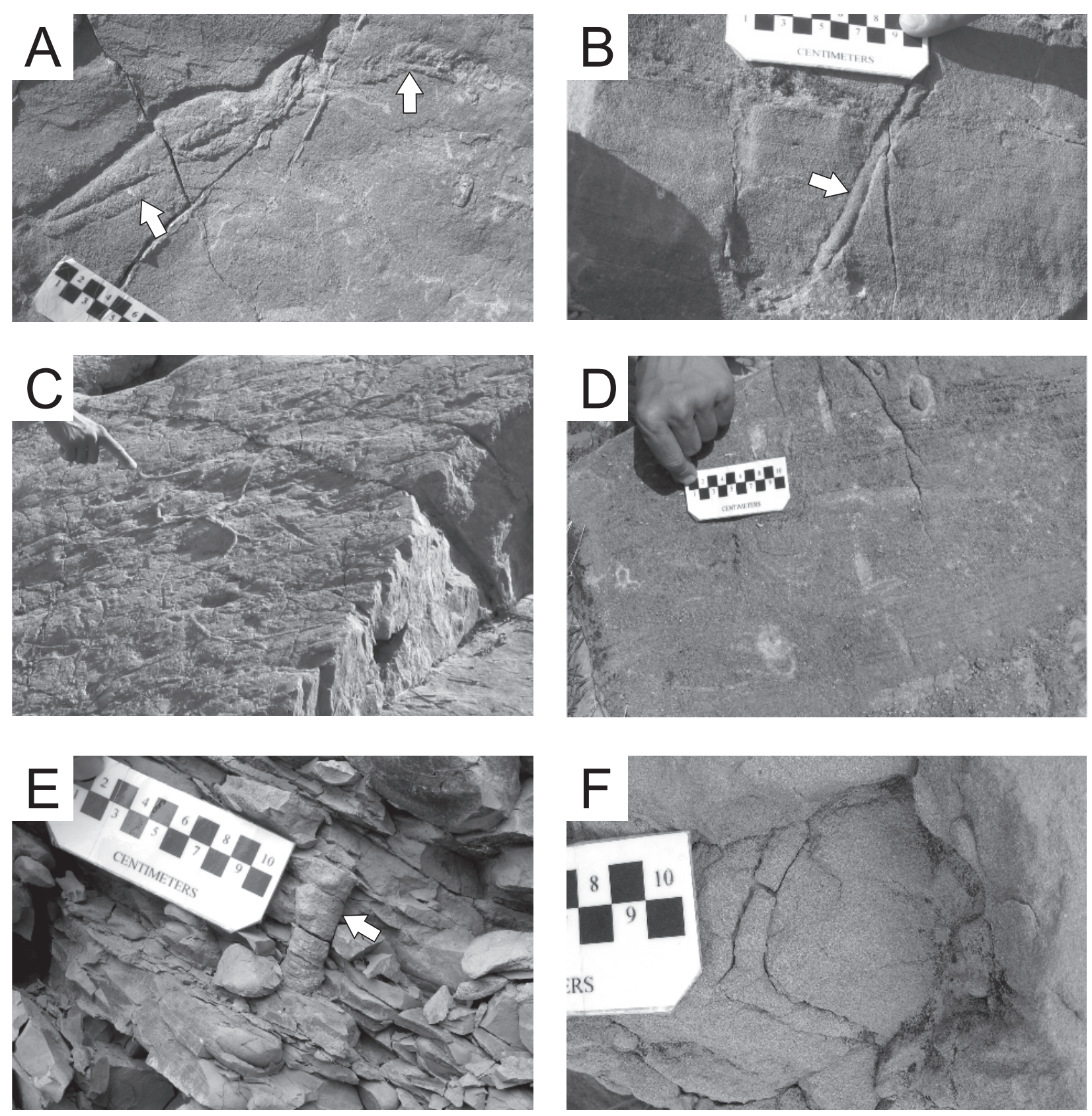

Fig. 12. Trace fossils. Scales in cm. A: Laminites kaitiensis in massive sandstone. B: Arenicolites forming a simple, vertical U-shaped tube. C: ?Mammal trackway in sandstone. D: Diplocraterion. E: Ophiomorpha in siltstone (arrow). F: Ophiomorpha in well-sorted sandstone.

haviour (which, indeed, partly depends on the environment). The distribution and behaviour of benthic organisms is limited by a number of palaeoecological factors such as the sedimentation rate, the nature of substrate, flow regimes, oxygen level and food resources (Pemberton et al., 2001). Thus, ichnofacies reflect similar environmental conditions during the production of trace fossils and have no meaning regarding evolution or time (Pemberton et al., 1992).
The trace fossils of the Kashkan Formation can for the major part be identified as typically belonging to the Scoyenia ichnofacies. This ichnofacies dominates the unconsolidated sedimentary cover on the continents and is characteristic of low-energy settings which are periodically subjected to subaerial conditions (MacEachern et al., 2007). Most Scoyenia settings are areas that become overflown occasionally with fresh water. Common depo- 

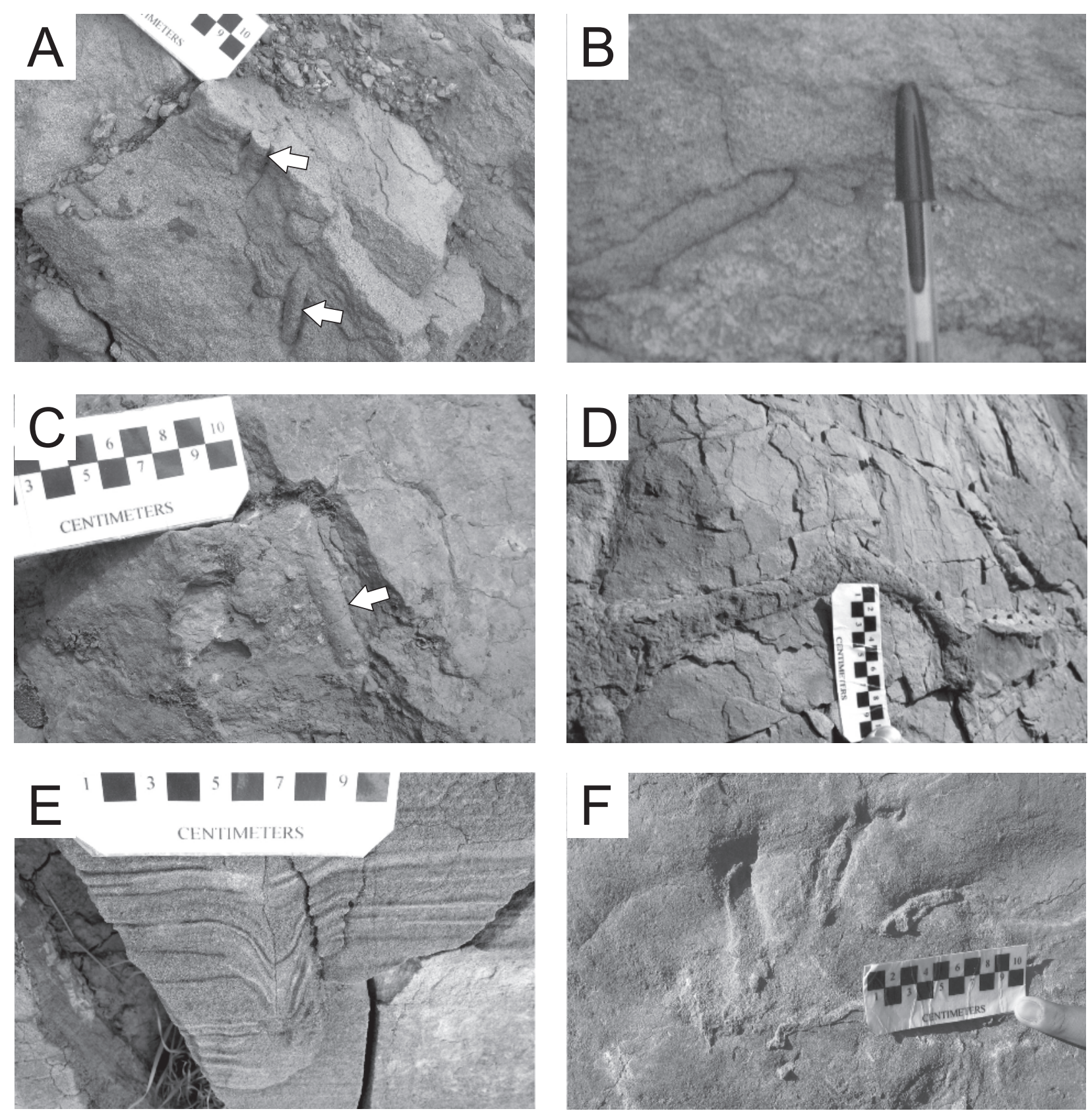

Fig. 13. Trace fossils. Scales in cm. A: Skolithos, as a vertical burrow in well-sorted sandstone. B: Skolithos, as a subvertical burrow. C: Steinichnus in massive sandstone. D: Thalassinoides in fine-grained sandstone. E: Escape structure with chevron pattern. F: Trackway in fine-grained sandstone.

sitional environments are lake margins, areas covered by braided streams, the channel margins and overbank areas (floodplains) of meandering rivers, and wet interdune areas (Frey \& Pemberton, 1984; Buatois \& Mángano, 2004).

Three ichnosubfacies of the Scoyenia ichnofacies can be distinguished on the basis of the trace fossils of the Kashkan Formation. They differ in lithofacies, frequency, energy-level changes and structures left by the organisms.
The three ichnosubfacies as distinguished in the Kashkan Formation are described shortly below. Figure 14 shows the interpreted tracefossil distributions in the Kashkan Formation, based on the concept of the Scoyenis ichnofacies.

\subsubsection{Skolithos-Arenicolites ichnosubfacies}

This ichnosubfacies includes abundant Arenicolites isp. and Skolithos isp. Ophiomorpha 


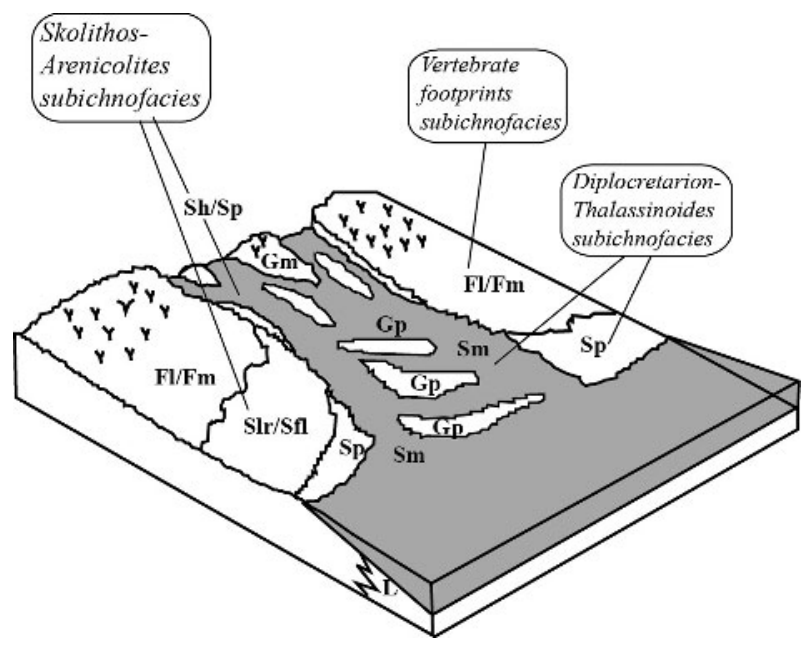

Fig. 14. Depositional model and palaeogeographical reconstruction (not to scale) of the Kashkan Formation and its Scoyenia ichnosubfacies.

isp. and Laminites karitiensis are common, while Steinichnus isp. and vertebrate tracks are relatively rare. This ichnosubfacies dominates particularly the Sm lithofacies as a lateral accretion and sandy bedform substratum.

\subsubsection{Diplocretarion-Thalassinoides ichnosubfacies}

In this ichnosubfacies, Diplocretarion isp. and Thalassinoides isp. are abundant, while Arenicolites isp., Skolithos isp., Ophiomorpha isp. and Laminites karitiensis are also present. This ichnosubfacies occurs in the Sh and Slr lithofacies.

\subsubsection{Ichnosubfacies of vertebrate footprints}

Vertebrate foot imprints are common in the Scoyenia ichnofacies. These trace fossils indicate at least temporary subaerial exposure This ichnosubfacies is found in the laminated and massive mudstone lithofacies ( $\mathrm{Fm}$ and $\mathrm{Fl}$ ).

\section{Genetic interpretation}

The Kashkan Formation is positioned in between two limestone formations with a distinctly marine fauna. The lower boundary is sharp, possibly representing a hiatus, whereas the upper boundary is formed by a limonitic interval. These boundaries suggest a change in the environmental conditions. In combination with the sudden change in lithology (the
Kashkan Fm. is siliciclastic) this suggests that the Kashkan Formation is not marine, but rather continental. This is supported by the absence of marine fossils, apart from some trace fossils that, as will be detailed below, may be marginal-marine.

The precise depositional environment(s) can be reconstructed on the basis of the combined information of the lithofacies, the architectural elements and the trace fossils (and their ichnofacies and ichnosubfacies). Obviously not each lithofacies, architectural element or trace fossil is diagnostic, but jointly they provide a good picture. We will therefore shortly mention here interpretations of the various parameters as commonly given in the literature.

\subsection{Lithofacies}

Lithofacies Gm: the internal characteristics and their lateral extent suggest that they were formed as longitudinal bars in gravelly rivers (cf. Hein \& Walker, 1977). This suggests that the entire facies developed due to processes that built longitudinal bars, as described by Williams \& Rust (1969). The erosional lower boundary fits well in this picture; it indicates that fluctuations in the current energy or turbulence led to erosion of the underlying sediments.

Lithofacies Gp is commonly interpreted as a product of the down-stream movement of transverse bars in low-sinuosity channels (cf. Miall, 1988; Pisarska-Jamrozy et al., 2010).

Lithofacies Gt developed as a result of the infilling of minor channels or depressions that were formed by scouring, and by the migration of 3-D gravel dunes (cf. Miall, 1977; Rust, 1978).

Lithofacies Sm was probably formed by rapid sedimentation after relaxation of a heavy sediment-laden flow (cf. Soegaard \& Eriksson, 1985; Maizels, 1993; Jo \& Chough, 2001; Simpson et al., 2002), but post-depositional deformation may also have played a role in forming the final texture (cf. Doe \& Dott, 1980; Allen, 1986; Tucker, 2003). Due to the lack of cross-bedding or horizontal stratification, it is impossible, however, to recognise soft-sediment deforma- 
tion structures (see Van Loon, 2009), so that we consider post-depositional deformation - if present - as of minor importance.

Lithofacies $\mathrm{Sp}$ was formed by the migration of straight-crested (2-D) dunes or bars deposited under conditions of the lower flow regime (cf. Miall, 1996; Capuzzo \& Wetzel, 2004).

In lithofacies St, the uniform orientation of the trough cross-bedding suggests a bedform typical of a fluvial environment (cf. Miall, 1996; Eriksson et al., 1998). These sandstones are interpreted as the product of 3-D dunes migrating in channels under conditions of the upper part of the lower flow regime, and of the infilling of depressions formed by scouring (cf. Miall, 1977; Harms et al., 1982; Collinson \& Thompson, 1989).

Lithofacies Sh has been commonly interpreted as due to migration of either low-amplitude bedforms or deposition under the plane-bed conditions of the upper flow regime (Allen, 1984; Bridge, 1993). Alternatively, the sandstones may derive from high-energy sheetfloods that spilled over from channels into a lower-energy environment during discharges that were too voluminous to be confined in the main fluvial channel system (Ghazi \& Mountney, 2009).

Lithofacies Slr represents alternating periods of ripple migration and settling from suspension during tidal cycles (Reineck \& Singh, 1980). The beds with current-generated ripples are common in sandy tidal flats (Meyer et al., 1998).

In lithofacies Sfl, the silt/ sand and mud alternations were formed in response to a fluctuating flow regime. The flasers of the type present here are common in a tidal-flat environment (Bhattacharaya \& Chakraborty, 2000).

Lithofacies Fl accumulated by settling of fine particles from suspension in an overbank setting. The red to purple colour is evidence of a well-drained, oxidising floodplain environment (cf. Mack \& James, 1992; Retallack, 1997).

Lithofacies L must, considering its finegrained character in combination with the occurrence of foraminifer fragments, have formed in ponds on a shoreface.

It thus turns out that a majority of the lithofacies $(\mathrm{Gm}, \mathrm{Gp}, \mathrm{Gt}, \mathrm{St}, \mathrm{Sh}, \mathrm{Fl})$ show characteris- tics that point to a fluvial origin; these characteristics are almost identical to those described from the South Saskatchewan River, which is a sandy braided river with deposits that can be easily - but erroneously - confused with those of a meandering river (Scholle \& Spearing, 1982). The large, complex braided system of the South Saskatchewan River has, however, like the sediments of the Kashkan Formation, more planar cross-bedded sets, more irregular grain-size trends and less floodplain sediments (Tucker, 1991).

A shoreface environment is indicated by lithofacies L, and shallow-marine conditions are indicated by lithofacies Slr and Sfl. Two lithofacies $(S m, S p)$ are insufficiently characteristic to ascribe them to a particular environment.

\subsection{Architectural elements}

The channel-fill elements $(\mathrm{CH})$, which are built by the three gravel and two fine-grained lithofacies and one sandstone lithofacies that were all interpreted as fluvial (with, in addition, one sandstone facies of unknown nature), are in all respects characteristic of a river environment.

The gravel-bar elements (GB) are commonly interpreted as consisting of fluvial transverse bars with a curved crest line (cf. Capuzzo \& Wetzel, 2004).

The sandy-bedform elements (SB) are commonly considered to represent the deposits of migratory dune-shaped bedforms in either mid-channel bars or on the flanks of point bars (Cant \& Walker, 1978; Miall, 1985).

Downstream-accretion elements (DA) are commonly formed by migrating linguoid or transverse bars (Collinson, 1996), commonly in a fluvial setting.

Laminated-sand-sheet elements (LS) suggest, according to Miall (1985), based on their sheet-like geometry and fine-grained lithology, deposition as a sand sheet on top or on the flank of a bar.

Floodplain elements (OF), with their sheetlike geometry and fine grain size, indicate deposition in a wide area with predominantly low-energy conditions. The red colour suggests 
intense oxidation, probably resulting from subaerial exposure. This is more common in floodplains than in a marginal marine setting.

Lateral-accretion elements are commonly interpreted as representing components of point bars (Olsen, 1988).

Taken all characteristics of the various architectural elements together, the conclusion must be that most units of the Kashkan Formation were deposited in an extensive braided setting. It should be noticed, however, that the analysis of these elements was largely based on the work by Miall (1985, 1994, 1997), who focused on fluvial architecture. It is therefore well possible that elements suggestive of another depositional environment have not been established equally well.

\subsection{Trace fossils and their ichno(sub)facies}

Not all trace fossils are diagnostic for a specific depositional environment, but some ichnospecies give some indications, which we mention below.

Arenicolites is generally associated with arenaceous substrates in a low-energy shoreface setting or in sandy tidal flats (Pemberton et al., 2001). It commonly indicates moist conditions and a high water table, typically above groundwater level (Hasiotis, 2006).

Diplocraterion is, based on analysis its morphological features, interpreted as the dwelling burrow of a suspension-feeder (Fürsich, 1974). This trace is a common element in the distal zone of the Skolithos ichnofacies in middle shoreface settings; it is also common on sandy tidal flats (Pemberton et al., 2001).

Laminites kaitiensis is reported from the littoral zone (Narbonne, 1981) and from marginalmarine environments (Webby, 1969) but has also been found in flysch deposits (Ghent and Henderson, 1966).

Ophiomorpha represents the dwelling burrow of a suspension-feeding shrimp and is commonly associated with the Skolithos ichno- facies, and abounds in marine shoreface environments (Pemberton et al., 2001).

Skolithos can be constructed by numerous organisms, and is found in almost all environments, from marine to continental (Pemberton et al., 2001).

Steinichnus is produced by either mud-loving beetles or mole crickets, and commonly is found in wet habitats associated with alluvial and marginal lacustrine environments (Hasiotis, 2006).

Thalassinoides is generally regarded as a dwelling or feeding burrow and is associated with the Cruziana ichnofacies in lower shoreface to offshore environments (Pemberton et al., 2001).

Escape structures do not indicate a specific environment, but reflect rather a setting where pulses of sediment result occasionally in a sudden, fast vertical accumulation.

Tracks are typically found in alluvial, aeolian and marginal-marine environments (Figs 12-C and 13-F).

The above environmental interpretations are based on literature data. Such data have been used by ichnologists to establish ichnofacies and ichnosubfacies. As mentioned above, all trace fossils found in the Kashban Formation fit in the Skoyenia ichnofacies, which can here be subdivided in three ichnosubfacies which allow a more detailed palaeoenvironmental reconstruction.

The Skolithos-Arenicolites ichnosubfacies is characteristic of a high energy level with a high supply of sandy sediment, mainly in channels.

The Diplocretarion-Thalassinoides ichnosubfacies occurs in the Kashkan Formation in sediments that were probably deposited by sheetfloods, indicating periodical changes in energy level.

The ichnosubfacies with footprints of birds and mammals indicates muddy areas, probably either floodplains of a river or shoreface areas that are alternatingly submerged and subaerially exposed, for instance due to tidal activity.

Taken all together, the trace fossils indicate both a fluvial and a shoreface setting. 


\section{Depositional environment and palaeogeography}

It appears from the above environmental reconstruction of the Kashkan Formation, based on lithofacies, architectural elements and trace fossils, that the various sediments were deposited in a low-gradient river system (cf. Weckwerth, 2011). The deposits of this system closely resemble those of the South Saskatchewan River in Canada, which is now considered as the classical example of a sand-bed braided river after the descriptions by Cant (1978) and Cant and Walker (1978). The river reached the shoreline of the continent. The seven measured sections and the lateral relationships between them confirm this interpretation, but provide also insight into the lateral and vertical facies changes.

The upper part of the Kashkan Formation is built mainly by conglomerates. This thick conglomerate unit thins toward the South and South-West. This suggests that the source area of the conglomerates was situated North to North-East of the study area.

The conglomerates, mainly lithofacies Gm, $\mathrm{Gp}$ and Gt, represent longitudinal bars (Gm), channel lag deposits $(\mathrm{Gm})$ and linguoid transverse bars ( $\mathrm{Gp}$ and $\mathrm{Gt}$ ). The few interbedded sandstone lenses represent periods of decreased stream competency. Other sandy lithofacies formed during stages of small discharge as a result of the migration of linguoid or straight-crested transverse bars (Sp) and of sinuous dunes or sinuous bars (St) when sand supply dominated in an active channel (cf. Miall, 1985). During stages of high discharge, the river overflowed the alluvial plains, where massive or laminated fine-grained material was left behind (Fm, Fl).

In the south-western part of the study area, the river embouched in a tidally influenced sea, as indicated by sands with flasers and crossbedding indicating opposite current directions (Sfl and Slr), and by the presence of foraminifer fragments.

This facies-based picture is supported by the distribution of the various architectural elements (Fig. 6). In the sections closest to the source area, such as the Darabi section, not only are conglomeratic units the most common, but the sedimentary cycles also consist mainly of $\mathrm{CH}$ and $\mathrm{GB}$ elements. In contrast, the intermediate Mamoolan and Golgekhalag sections, which are somewhat more fine-grained, show sedimentary cycles with more $\mathrm{CH}, \mathrm{GB}$, $\mathrm{SB}$ and OF elements. These sections also contain the trace fossil Skolithos. The fairly southern Moorani and Malavi sections, which are even finer-grained, comprise some intervals with carbonate facies (limestones and dolomites), indicating a marine setting, which is supported by the occurrence of escape structures and the trace fossil Diplocraterion, which are indicative of a shoreface environment. The southernmost section (the Sepiddasht section) contains abundant trace fossils such as Thalassinoides and Ancorichnus, and fine-grained facies are very common.

\section{Conclusions}

The Kashkan Formation (?Palaeocene to Middle Eocene) in SW Iran mainly consists of coarse, medium and fine siliciclastic lithofacies in which no fossils, apart from trace fossils, occur. This is in strong contrast with the under- and overlying formations that consist of fossiliferous marine limestones. The sharp boundaries with the under- and overlying formations indicate abrupt changes in the depositional conditions. A sudden change is reflected not only by the different lithology, but also by the sedimentological characteristics (lithofacies and architectural elements), which indicate that the sediments were deposited in a fluvial environment that had occasionally meandering (overbank deposits, large bars) and but mainly braided (mainly unidirectional palaeocurrent directions, sheetfloods) characteristics (Fig. 14). Meandering and braided behaviour may have changed from time to time during its depositional history. This is confirmed by the ichnofauna. The river ran roughly from North to South in the study area. In the South and South-West, the river reached a shoreface environment, as indicated by the trace fossils. 


\section{Acknowledgements}

We are grateful to all members of the Lorestan University for cooperation in the field. Dr. Hasan Mohseni is thanked for providing the microscope facilities at Hamedan University.

\section{References}

Alavi, M., 2004. Regional stratigraphy of the Zagros fold-thrust belt of Iran and its proforeland evolution. American Journal of Science 304, 1-20.

Allen, J.R.L., 1964. Studies in fluviatile sedimentation: six cyclothems from the Lower Old Red Sandstone, Anglo-Welsh Basin. Sedimentology 3,163-198.

Allen, J.R.L., 1983. Studies in fluviatile sedimentation: bars, bar-complexes and sandstone sheets (low-sinuosity braided streams) in the Brownstones (L. Devonian), Welsh Borders. Sedimentary Geology 33, 237-293.

Allen, J.R.L., 1984. Parallel lamination developed from upper stage plane beds: a model based on the larger coherent structures of the turbulent boundary layer. Sedimentary Geology 39, 227-242.

Allen, J.R.L., 1986. Earthquake magnitude-frequency, epicentral distance, and soft-sediment deformation in sedimentary basins. Sedimentary Geology 46, 67-75.

Anderson, B.G. \& Droser, M.L., 2000. Ichnofabrics and geometric configurations of Ophiomorpha within a sequence stratigraphy framework: an example from the Upper Cretaceous US western interior. Sedimentology 45, 379-396.

Bhattacharayya, A. \& Chakraborty, C., 2000. Analysis of Sedimentary Successions, a Field Manual. A.A. Balkema Publishers, Dordrecht, 408 pp.

Bridge, J.S., 1985. Paleochannel patterns inferred from alluvial deposits: a critical evaluation. Journal of Sedimentary Petrology 55, 579-589.

Bridge, J.S., 1993. Description and interpretation of fluvial deposits: a critical perspective. Sedimentology 40, 801-810.

Bridge, J.S., 2006. Fluvial facies models: recent developments. In: Posamentier, H. \& Walker, R.G. (Eds), Facies Models Revisited. SEPM Special Publication, 84, p. 85-170.

Brierley, G.J., 1996. Channel morphology and element assemblages: a constructivist approach to facies modelling. In: Carling, P.A. \& Dawson, M.R. (Eds), Advances in Fluvial Dynamics and Stratigraphy. John Wiley \& Sons, Chichester, pp. 263-298.

Cant, D.J., 1978. Bedforms and bar types in the South Saskatchewan River. Journal of Sedimentary Petrology 48, 1321-1330.

Cant, D.J. \& Walker, R.G., 1978. Fluvial processes and facies sequences in the sandy braided South Saskatchewan River, Canada. Sedimentology 25, 625-648.

Capuzzo, N. \& Wetzel, A., 2004. Facies and basin architecture of the Late Carboniferous Salvan-Dorénaz continental basin (Western Alps, Switzerland/France). Sedimentology 51, 675-697.
Collinson, J.D., 1996. Alluvial sediments. In: Reading, H.G. (Ed.), Sedimentary Environments: Processes, Facies and Stratigraphy (3rd ed.). Blackwell Publishing, Oxford, p. 37-82.

Collinson, J.D. \& Thompson, D.B., 1989. Sedimentary Structures (2nd ed.). Unwin Hyman, London, 207 pp.

Crimes, T.P. \& Droser, M.L., 1992. Trace fossils and bioturbation: the other fossil record. Annual Review of Ecological Systems 23, 339-360.

D’Alessandro, A., Ekdale, A.A. \& Picard, M.D., 1987. Trace fossils in fluvial deposits of the Duchesne River Formation (Eocene), Uinta Basin, Utah. Palaeogeography, Palaeoclimatology, Palaeoecology 61, 285-301.

Doe, T.W. \& Dott, R.H. Jr., 1980. Genetic significance of deformed cross-bedding-with examples from the Navajo and Weber sandstones of Utah. Journal of Sedimentary Petrology 50, 793-812.

Eriksson, P.G., Condie, K.C., Tirsgaard, H., Muller W.U., Altermann, W., Miall, A.D., Aspler, L.B., Catuneanu, O. \& Chiarenzelli, J.R., 1998. Precambrian clastic sedimentation systems. Sedimentary Geology 120, 5-53.

Falcon, N.L., 1967. The geology of northeast margin of Arabian basement shield. Advances in Science (Sept. 1967), 31-42.

Frey, R.W., Howard, J.D. \& Pryor, W.A., 1978. Ophiomorpha: its morphologic, taxonomic, and environmental significance. Palaeogeography, Palaeoclimatology, Palaeoecology 23, 199-229.

Frey, R.W. \& Pemberton, S.G., 1984. Trace fossil facies models. In: Walker R.G. (Ed.), Facies Models. Geoscience Canada Reprint Series 1, p. 189-207.

Friend, P.F., 1983. Towards the field classification of alluvial architecture or sequence. In: Collinson J.D., Lewin, J. (Eds), Modern and Ancient Fluvial Systems. Special Publication International Association of Sedimentologists, p. 345-354.

Fürsich, F.T., 1974. On Diplocraterion Torell 1870 and the significance of morphological features in vertical, spreite-bearing, U-shaped trace fossils. Journal of Paleontology 48, 952-962.

Ghazi, S. \& Mountney, N.P, 2009. Facies and architectural element analysis of a meandering fluvial succession: the Permian Warchha Sandstone, Salt Range, Pakistan. Sedimentary Geology 221, 99-126.

Ghent, E.G. \& Henderson, R.A., 1966. Petrology, sedimentation and palaeontology of Middle Miocene graded sandstones and mudstone, Kaiti beach, Gisborne. Transactions of the Royal Society of New Zealand (Geology) 4, 147-169.

Harms, J.C., Southard, J.B. \& Walker, R.G., 1982. Structures and Sequences in Clastic Rocks. SEPM Short Course Notes 9, 851 pp.

Hasiotis, S.T., 2006. Continental Trace Fossils. SEPM Short Course Notes 51, 134 pp.

Hein, F.J. \& Walker, R.G., 1977. Bar evolution and development of stratification in the gravelly, braided Kicking Horse River, British Coloumbia. Canadian Journal of Earth Sciences 14, 562-570.

Hjellbakk, A., 1997. Facies and fluvial architecture of a high-energy braided river: the Upper Proterozoic 
Seglodden Member, Varanger Peninsula, northern Norway. Sedimentary Geology 114, 131-141.

Jackson II, R.G., 1981. Sedimentology of muddy finegrained channel deposits in meandering streams of the American Middle West. Journal of Sedimentary Petrology 51, 1169-1192.

James, G.A. \& Wynd, J.G., 1965. Stratigraphic nomenclature of Iranian oil consortium agreement area. American Association of Petroleum Geologists Bulletin 49, 2182-2245.

Jo, H.R. \& Chough, S.K., 2001. Architectural analysis of fluvial sequences in the northwestern part of Kyongsang Basin (Early Cretaceous), SE Korea. Sedimentary Geology 144, 307-334.

Jones, S.J., Frostick, L.E. \& Astin, T.R., 2001. Braided stream and flood plain architecture: the Rio Vero Formation, Spanish Pyrenees. Sedimentary Geology 139, 229-260.

Leturmy, P. \& Robin, C. (Eds), 2010. Tectonic and stratigraphic evolution of Zagros and Makran during the Mesozoic-Cenozoic. Geological Society, London, Special Publication 330, 376 pp.

López-Gómez, J., Martin-Chivelet, J.M. \& Palma, R., 2009. Architecture and development of the alluvial sediments of the Upper Jurassic Tordillo Formation in the Cañada Ancha Valley, northern Neuquén Basin, Argentina. Sedimentary Geology 219, 180-195.

Mack, G.H. \& James, W.C., 1992. Paleosols for Sedimentologists. Geological Society of America Short Course Notes, $127 \mathrm{pp}$.

Maizels, J., 1993. Lithofacies variations within sandur deposits: the role of runoff regime, flow dynamics and sediment supply characteristics. Sedimentary Geology 85, 299-325.

Mazumder, R. \& Sarkar, S., 2004. Sedimentary history of the Palaeoproterozoic Dhanjori Formation, Singhbhum, India and its implications. Precambrian Research 130, 267-287.

Meyer, R., Krause, F. \& Braman, D., 1998. Unconformities within a progradational estuarine system: the Upper Santonian Virgelle Member, Milk River Formation, Writing-on-Stone Provincial Park, Alberta, Canada. In: Alexander, C.R. \& Henry, V.J. (Eds), Tidalites: Processes and Products. SEPM Special Publication 61, p. 129-142.

Miall, A.D., 1985. Architectural-element analysis: a new method of facies analysis applied to fluvial deposits. Earth-Science Reviews 22, 261-308.

Miall, A.D., 1988. Reservoir heterogeneities in fluvial sandstones: lessons from outcrop studies. American Association of Petroleum Geologists Bulletin 72, 682-697.

Miall, A.D., 1994. Reconstructing fluvial macrofrom architecture from two-dimensional outcrops; examples from the Castlegate Sandstone, Book Cliffs, Utah. Journal of Sedimentary Research 64, 146-158.

Miall, A.D., 1996. The Geology of Fluvial Deposits, Sedimentary Facies, Basin Analysis and Petroleum Geology. Springer- Verlag, Berlin, 582 pp.

Miall, A.D., 1997. A review of the braided-river depositional environment. Earth-Science Reviews 13, 1-62.
Motiei, H., 1993. Stratigraphy of Zagros. Treatise on the Geology of Iran. Geological Survey of Iran, Teheran, $536 \mathrm{pp}$. [in Persian].

Murris, R.J., 1978. Hydrocarbon habitat of the Middle East. Shell Internationale Petroleum Maatschappij B.V., Exploration and Production, 179.

Murris, R.J., 1980. The Middle East: stratigraphic evolution and oil habitat. American Association of Petroleum Geologists Bulletin 64, 597-618.

Narbonne, G.M., 1981. Stratigraphy, reef development and trace fossils of the Upper Silurian Douro Formation in the southeastern Canadian Arctic Island. Ph.D. Thesis University of Ottawa, $259 \mathrm{pp}$.

Olsen, H., 1988. The architecture of a sandy braidedmeandering river system: an example from the lower Triassic Solling Formation (M. Buntsandstein) in WGermany. Geologische Rundschau 77, 797-814.

Pemberton, S.G., Spila, M., Pulham, A.J., Saunders, T., MacEachern, J.A., Robbins, D. \& Sinclair, I.K., 2001. Ichnology and sedimentology of shallow to marginal marine systems. Geological Association of Canada Short Course Notes 15, 343 pp.

Pisarska-Jamrozy, M., Machowiak, K. \& Krzyszkowski, D., 2010. Sedimentation style of a Pleistocene kame terrace from the western Sudety Mountains, S Poland. Geologos 16, 101-110.

Reineck, H.E. \& Singh, I.B., 1980. Depositional sedimentary environments (with reference to terrigenous clastics) (2nd ed.). Springer-Verlag, Heidelberg, 549 pp.

Retallack, G.J., 1997. A Colour Guide to Paleosols. John Wiley \& Sons, Chichester, 175 pp.

Rust, B.R., 1978. A classification of alluvial channel systems. In: Miall, A.D. (Ed.), Fluvial Sedimentology. Canadian Society of Petroleum Geologists Memoir 5, p. 187-198.

Salamon, T. \& Zielinski, T., 2010. Unusual development of sandur sedimentary succession, an example from the Pleistocene of S Poland. Geologos 16, 83-99.

Scholle, P.A. \& Spearing, D., 1982. Sandstone Depositional Environments. American Association of Petroleum Geologists Memoir 31, $410 \mathrm{pp}$.

Setudehnia, A., 1978. The Mesozoic sequence in southwest Iran and adjacent areas. Journal of Petroleum Geology 1, 3-42.

Simpson, E.L., Dilliard, K.A., Rowell, B.F. \& Higgins, D., 2002. The fluvial-to-marine transition within the post-rift Lower Cambrian Hardyston Formation, eastern Pennsylvania, USA. Sedimentary Geology 147, 127-142.

Soegaard, K. \& Eriksson, K.A., 1985. Evidence of tide, storm, and wave interaction on a Precambrian siliciclastic shelf: the 1700 m.y. Ortega Group, New Mexico. Journal of Sedimentary Research 55, 672-684.

Stocklin, J., 1968. Salt deposits of the Middle East. Geological Sociey of America Special Paper 88, 157-181.

Stocklin, J., Ruttner, A. \& Nabavi, M., 1964. New data on the Lower Paleozoic and Pre-cambrian of North Iran. Geological Survey of Iran, Reports 1, 29 pp.

Stow, D.A.V., 2005. Sedimentary Rocks in the Field, a Colour Guide. Manson Publishing, 320 pp. 
Szabo, F., 1977. Permian and Triassic stratigraphy of Fars area. Proceedings of the Second Geological Symposium 'Southwest Iran' (Tehran, March 1977). The Iranian Petroleum Institute.

Szabo, F. \& Kheradpir, A., 1978. Permian and Triassic Stratigraphy, Zagros basin, Southwest Iran. Journal of Petroleum Geology 1, 57-82.

Tucker, M.E., 1991. Sedimentary Petrology - An Introduction on the Origin of Sedimentary Rocks. Blackwell Scientific Publications, Oxford, $260 \mathrm{pp}$.

Tucker, M.E., 2003. Sedimentary Rocks in the Field (3rd ed.). John Wiley \& Sons, 234 pp.

Van Loon, A.J., 2009. Soft-sediment deformation structures in siliciclastic sediments: an overview. Geologos 15, 3-55.

Webby, B.D., 1968. Devonian trace fossils from Beacon Group, Antarctica. New Zealand Journal of Geology and Geophysics 11, 1001-1008.
Weckwerth, O., 2011. Palaeoslopes of Weichselian sandbed braided rivers in the Torun Basin (Poland): results of a palaeohydraulic analysis. Geologos 17, 227-238.

Willis, B.J., 1993. Ancient river systems in the Himalayan foredeep, Chinji Village area, northern Pakistan. Sedimentary Geology 88, 1-76.

Williams, P.F. \& Rust, B.R., 1969. The sedimentology of a braided river. Journal of Sedimentary Petrology 39, 649-679.

Manuscript received: 1 February 2012 Revision accepted: 15 March 2012 